\title{
Building Information Modelling, Lean and Sustainability: An integration framework to promote performance improvements in the construction industry
} DOI:

10.1016/j.scs.2020.102355

\section{Document Version \\ Accepted author manuscript}

Link to publication record in Manchester Research Explorer

Citation for published version (APA):

Mellado, F., \& Lou, E. (2020). Building Information Modelling, Lean and Sustainability: An integration framework to promote performance improvements in the construction industry. Sustainable Cities and Society.

https://doi.org/10.1016/j.scs.2020.102355

\section{Published in:}

Sustainable Cities and Society

\section{Citing this paper}

Please note that where the full-text provided on Manchester Research Explorer is the Author Accepted Manuscript or Proof version this may differ from the final Published version. If citing, it is advised that you check and use the publisher's definitive version.

\section{General rights}

Copyright and moral rights for the publications made accessible in the Research Explorer are retained by the authors and/or other copyright owners and it is a condition of accessing publications that users recognise and abide by the legal requirements associated with these rights.

\section{Takedown policy}

If you believe that this document breaches copyright please refer to the University of Manchester's Takedown Procedures [http://man.ac.uk/04Y6Bo] or contact uml.scholarlycommunications@manchester.ac.uk providing relevant details, so we can investigate your claim.

\section{OPEN ACCESS}




\title{
Building Information Modelling, Lean and Sustainability: An integration framework to promote performance improvements in the construction industry.
}

\author{
Felipe Mellado ${ }^{12^{\wedge}}$, Eric C.W. Lou ${ }^{3}$ \\ ${ }^{1}$ School of Mechanical, Aerospace and Civil Engineering, University of Manchester, UK. \\ ${ }^{2}$ Innovation Centre of Applied Engineering, Universidad Católica del Maule, Talca, Chile. \\ ${ }^{3}$ School of Engineering, Manchester Metropolitan University, Manchester, UK.
}

$\wedge^{\wedge}$ Corresponding author.

Email: felipe.mellado@postgrad.manchester.ac.uk

Address: The University of Manchester, Oxford Rd, Manchester, M13 9PL, UK.

tel:+44 (0) 1613066000 


\section{Building Information Modelling, Lean and Sustainability: An integration framework to promote performance improvements in the construction industry.}

Highlights

- The construction industry is known for its impact on the environment.

- BIM, lean and sustainability improve processes whilst enhancing sustainability.

- The linkage has been suggested but comprehensive frameworks are still missing.

- An integration framework of BIM, lean and sustainability (BLS) is proposed. 
Building Information Modelling, Lean and Sustainability: An integration framework to promote performance improvements in the construction industry.

\section{Abstract}

The construction industry is known for its fragmentation, poor performance and negative impacts on the environment. In recent years, Building Information Modelling (BIM), lean principles and sustainability concerns have emerged as trends in the industry, since they aim to improve how buildings are delivered throughout their entire lifecycle. Value aggregation and efficiency in operational and environmental terms are major concerns by stakeholders and wider society. Integrating these practices would yield better project outcomes. However, majority of studies are focused on these elements in isolation or in pairs and there are no comprehensive frameworks suggesting an integration. This study researched, analysed and articulated existing work on a possible integration framework of BIM, lean and sustainability principles (BLS) to promote performance improvements. Current proposals were analysed along with drivers, benefits, barriers and challenges for integration. Academics and industry practitioners will benefit from this framework as it looks into future requirements of the industry, which is aiming to achieve better efficiency and enhancement of sustainability outcomes.

Keywords: Building Information Modelling, lean, sustainability, construction 
Table 1: Research methods

\begin{tabular}{|c|c|}
\hline Unit of analysis & $\begin{array}{l}\text { The main source of analysis are journal papers. Books were excluded from } \\
\text { the main topic analysis. Conference proceedings were included as well }\end{array}$ \\
\hline Type of analysis & Qualitative \\
\hline Period & $2000-2018$ \\
\hline Search Engines & $\begin{array}{l}\text { Elsevier (www.sciencedirect.com), Emerald } \text { (www.emeraldinsight.com), } \\
\text { Springer } \quad \text { (www.springerlink.com), Taylor \& Francis } \\
\text { (www.taylorandfrancis.com), and the Google Scholar database, or library } \\
\text { services (e.g., Wiley online library www.wiley. com) }\end{array}$ \\
\hline Keywords & $\begin{array}{l}\text { Building Information Modelling (BIM), Lean, Sustainability and the } \\
\text { combination of them, framework, model, Lean Production, Green. }\end{array}$ \\
\hline Number of articles & 215 \\
\hline
\end{tabular}


List of figures.

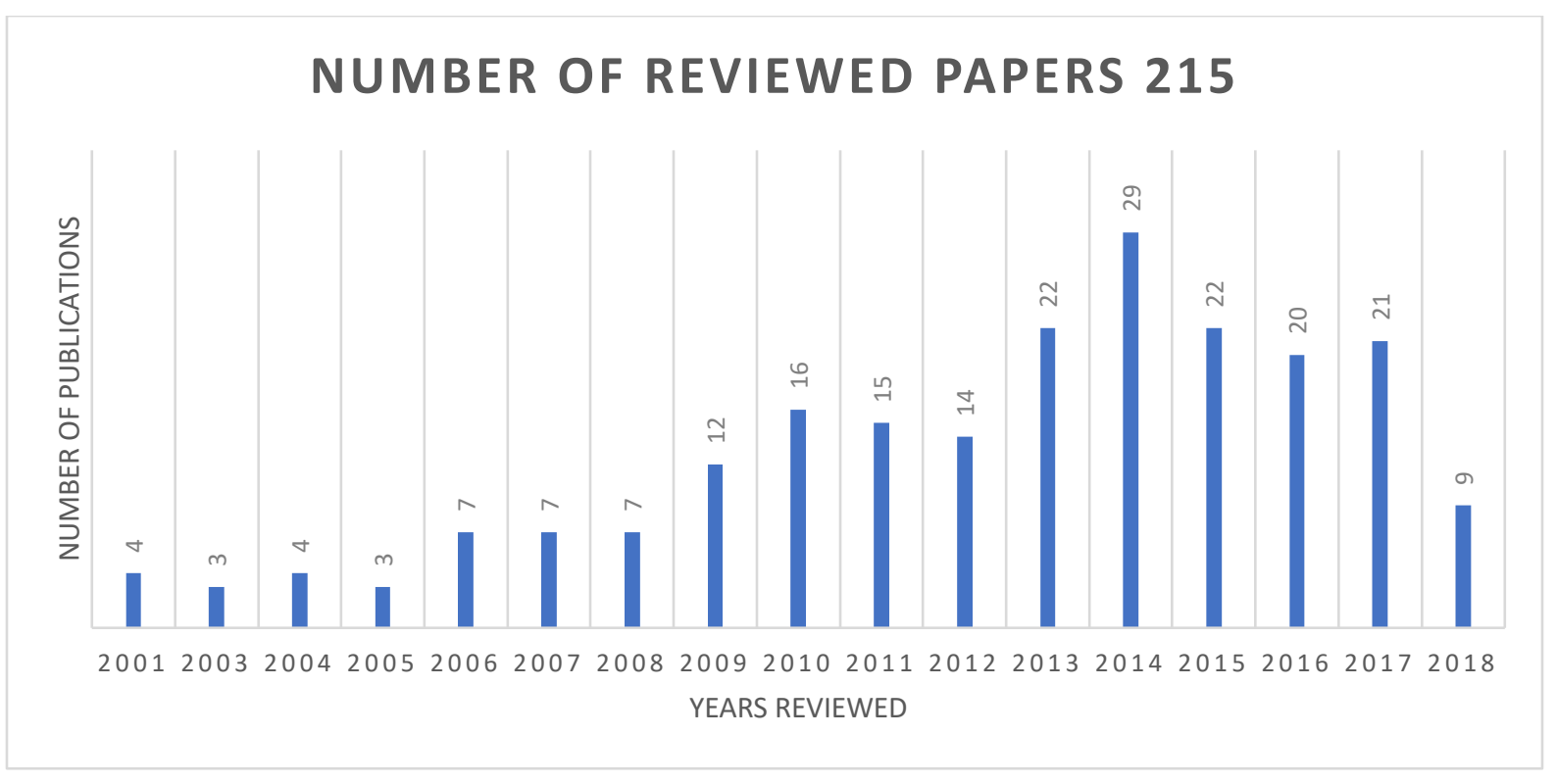

Figure 1: Number of reviewed papers 


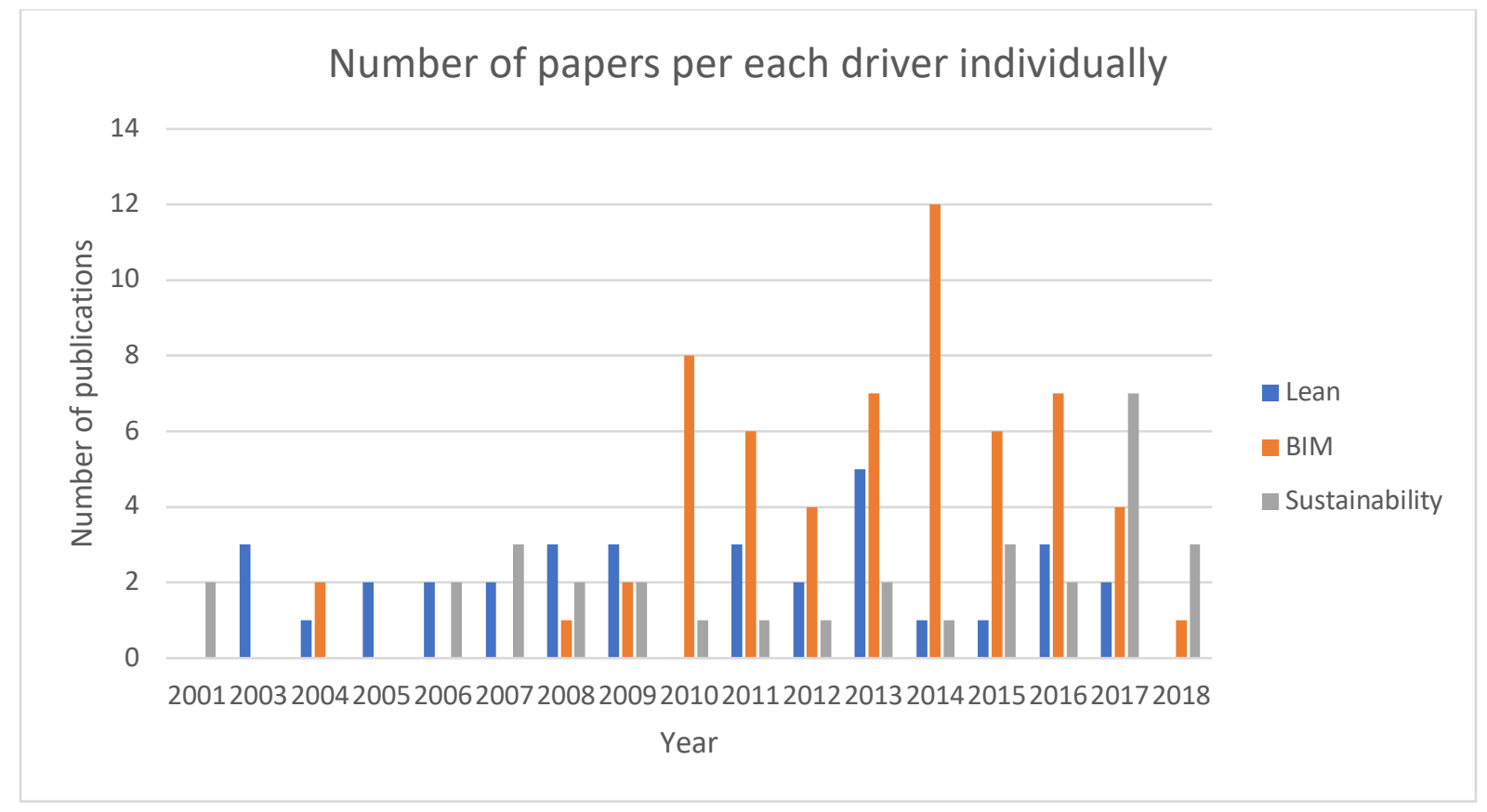

Figure 2: Number of papers per each driver individually 
Number of interactions found on the literature

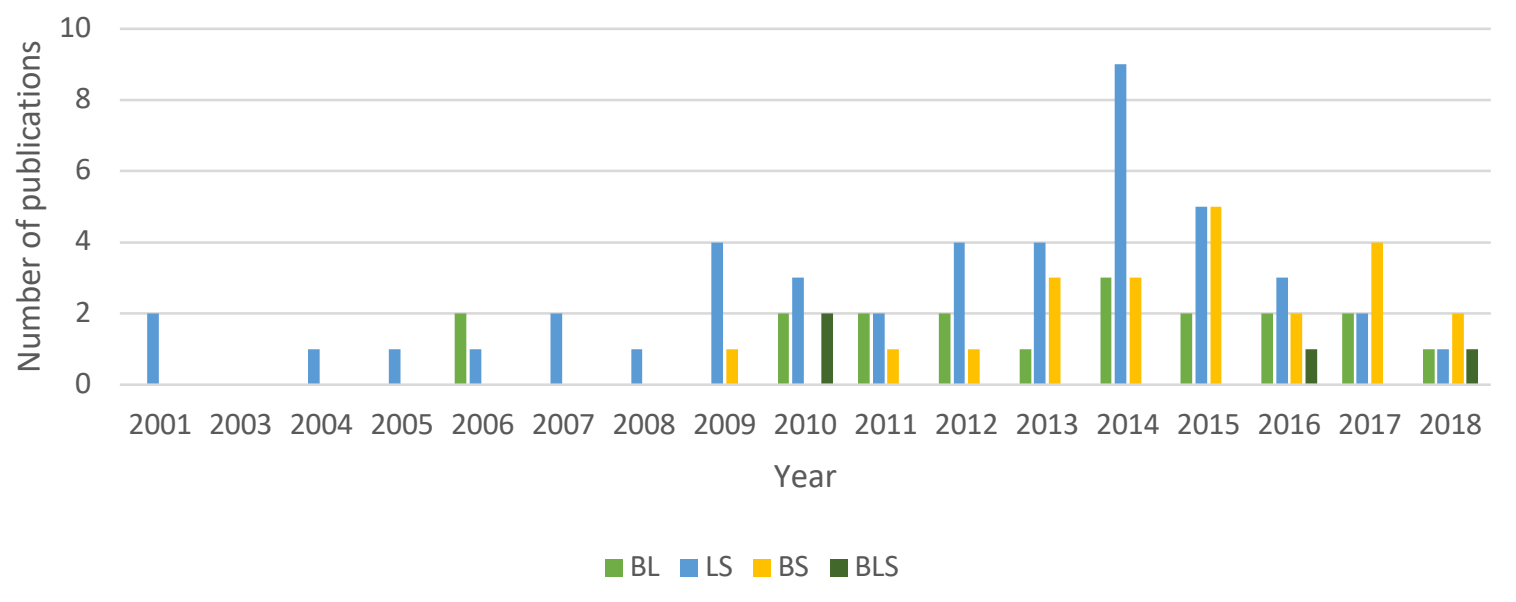

Figure 3: Number of interactions found on the literature 


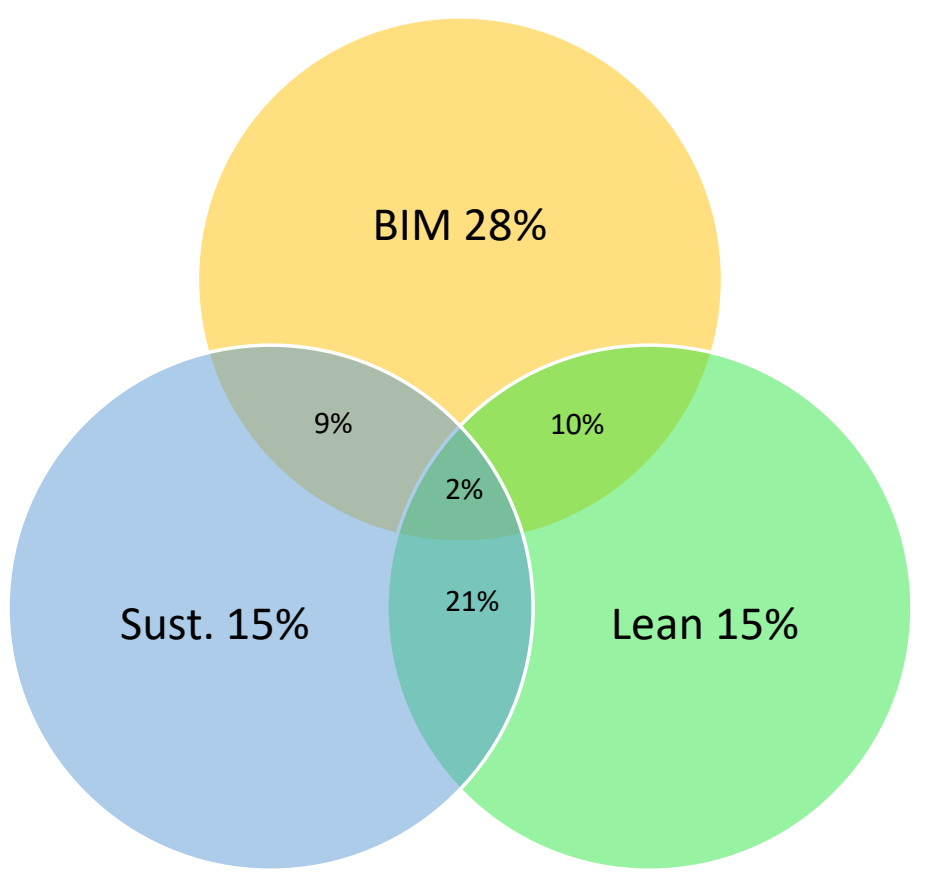

Figure 4: Percentage of research synergies 


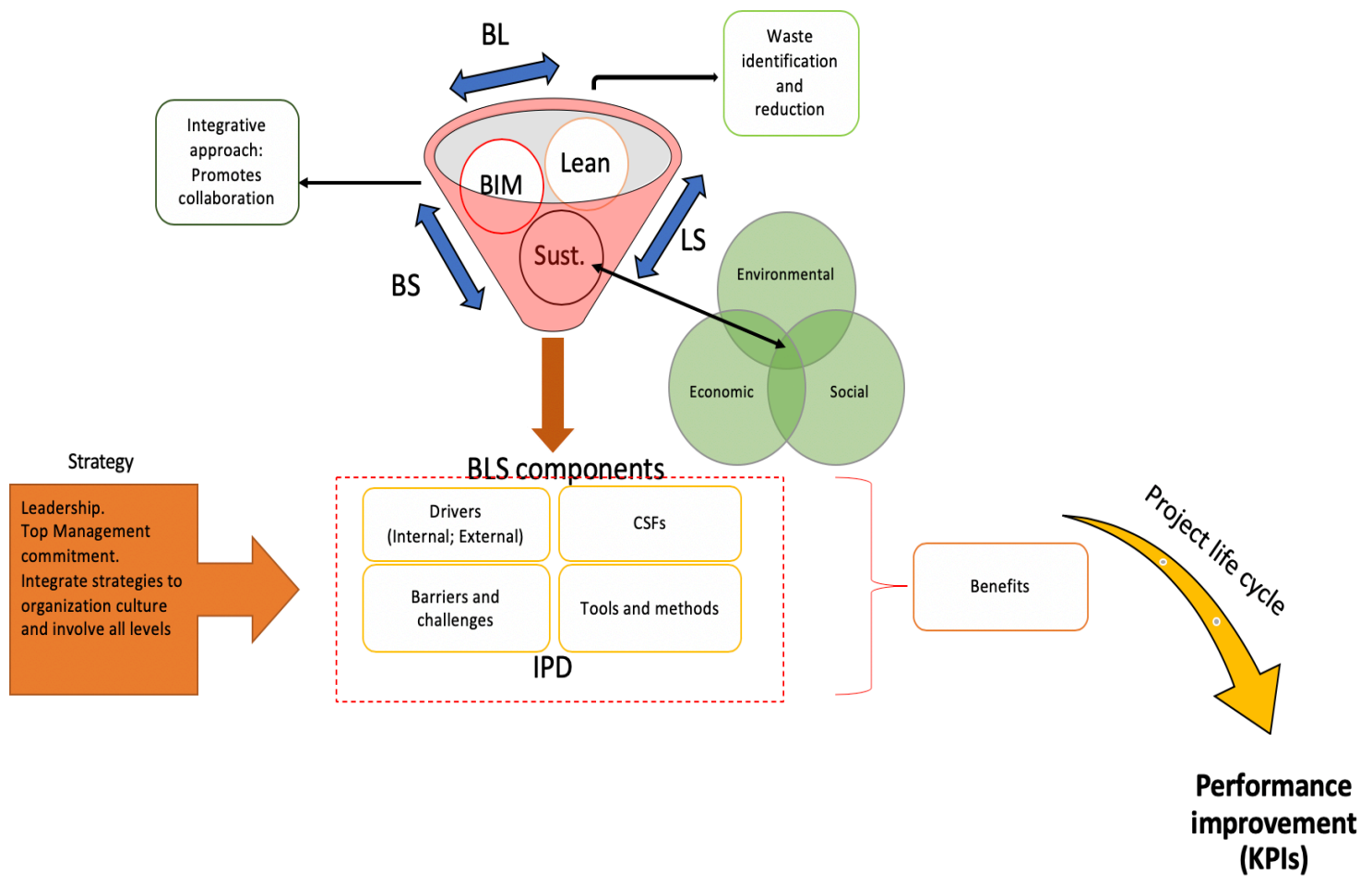

Figure 5: BLS theoretical framework and its components 


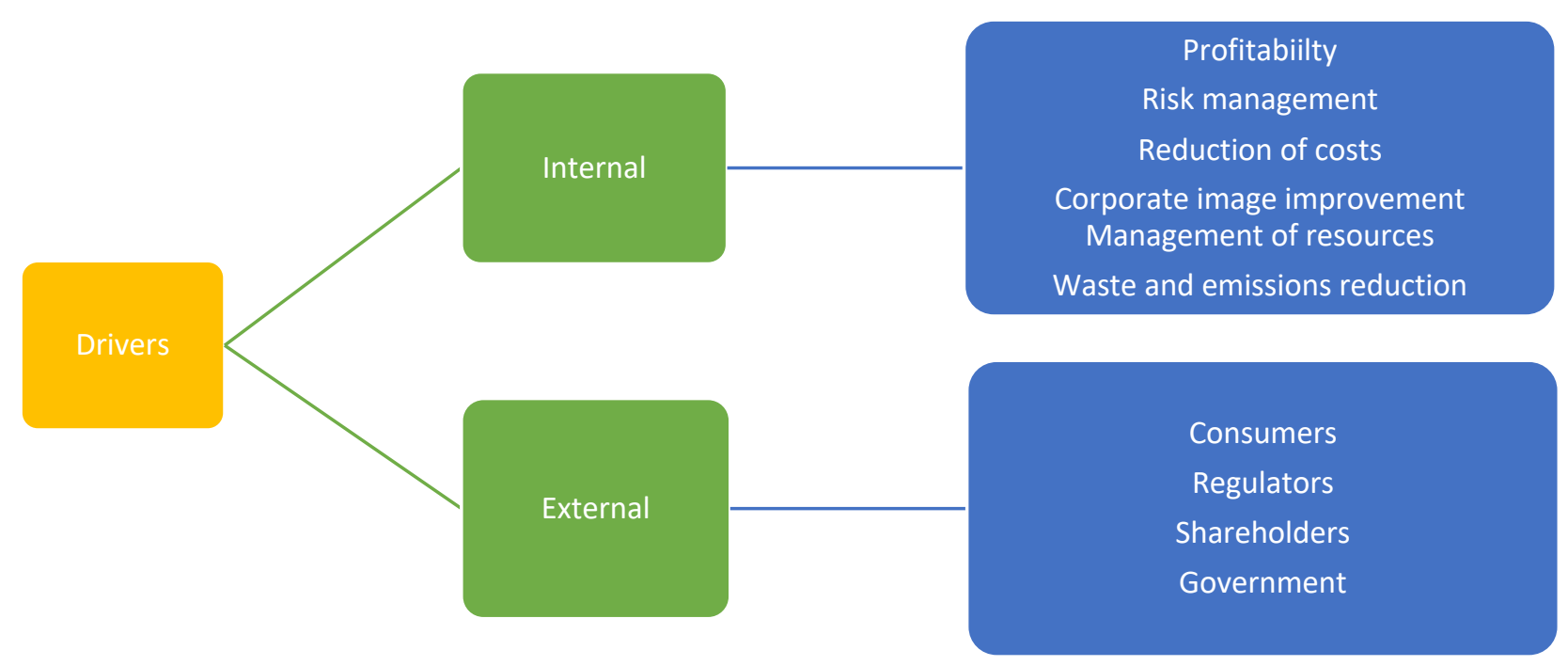

Figure 6: Integration drivers 


\section{BIM}

- Interoperability

- Lack of skills/experience

- Low return of investment

- Lack of knowledge from within organisations

- Lack of client demand

- Resistance to change

- Cost of investment

- Lack of extra project finance to fund BIM

- Unwillingness to share information

- Projects that have used BIM not having shown immediate benefits

- Legal aspects regarding model ownership

\section{Lean}

- Structural and cultural barriers

- Lack of adequate Lean awareness and understanding

- Lack of top management commitment

- Cultural and human attitudinal issues

Figure 7: Integration barriers

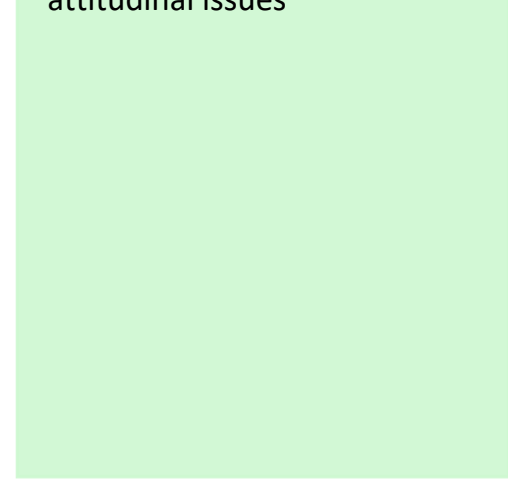

\section{Sustainability}

- Lack of environmental awareness

- Perception of higher costs

- Disconnect between environmental and continuous improvement decisions by organisations

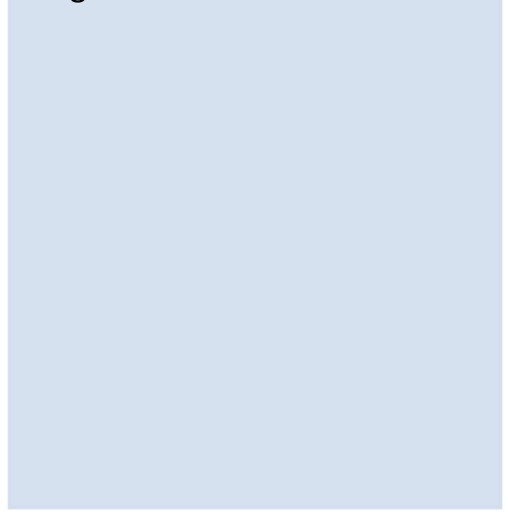


Table 2: BIM and Lean applications

\begin{tabular}{|c|c|c|}
\hline Reference & Method & Results \\
\hline Rischmoller et al. (2006) & $\begin{array}{l}4 \text { years' case study in the design stage of a } \\
\text { construction project, applying "Computed } \\
\text { advanced visualisation tools" (CAVT). }\end{array}$ & Improved customer value and flow, and waste reduction. \\
\hline Sacks et al. (2009) & $\begin{array}{l}\text { Study of the contributions of BIM to visualise both } \\
\text { product and process in construction projects in } \\
\text { terms of Lean construction practices. }\end{array}$ & $\begin{array}{l}\text { BIM use and similar technologies reduced the variability in construction } \\
\text { processes. }\end{array}$ \\
\hline Tauriainen et al. (2016) & $\begin{array}{l}\text { Identification of BIM implementation problems in } \\
\text { structural and building services design } \\
\text { management. }\end{array}$ & BIM management and Lean tools, were recommended for problem solution. \\
\hline Shou et al. (2014) & $\begin{array}{l}\text { Case study showing the application of BIM and Lean } \\
\text { principles. }\end{array}$ & $\begin{array}{l}\text { Integration of BIM and Lean concepts in Oil and Gas maintenance show } \\
\text { improvements in efficiency. }\end{array}$ \\
\hline Mahalingam et al. (2015) & $\begin{array}{l}\text { Case study of two metro rail station projects to } \\
\text { assess the use of Lean practices for achieving } \\
\text { enhanced levels of BIM and to understand how Lean } \\
\text { practices can be used to enable BIM adoption. }\end{array}$ & $\begin{array}{l}\text { Lean practices promote BIM adoption. Reduction in coordination problems by } \\
\text { using Lean practices is also reported. BL integration lead to improvements in } \\
\text { project performance. }\end{array}$ \\
\hline Dave et al. (2011) & $\begin{array}{l}\text { Proposed a software called VisiLean to provide } \\
\text { visualisation of work status based on Lean } \\
\text { principles. }\end{array}$ & $\begin{array}{l}\text { Tested successfully in the } \mathrm{Cl} \text { and in organisations, however practical } \\
\text { implementation has not been carried out. }\end{array}$ \\
\hline Gerber et al. (2010) & $\begin{array}{l}\text { Analysis of three case studies to explore the } \\
\text { relationship between Lean construction and BIM. }\end{array}$ & $\begin{array}{l}\text { Increased value to the clients, waste reduction in terms of time, materials and } \\
\text { financing. }\end{array}$ \\
\hline
\end{tabular}


Table 3: Examples of BIM and sustainability applications

\begin{tabular}{|c|c|c|}
\hline Reference & Method & Results \\
\hline Wong and Zhou (2015) & $\begin{array}{l}\text { Literature review on green-BIM literature } \\
\text { obtained from articles comprising a } 10- \\
\text { year period from } 2004 \text { to } 2014 \text {. }\end{array}$ & $\begin{array}{l}\text { Results show a lack of an all-inclusive green BIM tool that provides a 'cradle to grave' } \\
\text { management of a building. BIM is most commonly used in the early stages of building life } \\
\text { cycles and future BIM tools should include the reduce, reuse and recycle concept in their } \\
\text { sustainability analysis. }\end{array}$ \\
\hline Chong et al. (2016) & $\begin{array}{l}\text { Systematic review of } \text { BIM } \\
\text { standards/guidelines and their use for } \\
\text { sustainability. }\end{array}$ & $\begin{array}{l}\text { Lack of BIM research in refurbishment and demolition, new BIM tools are needed for } \\
\text { assessing sustainability criteria, improved interoperability between BIM software and } \\
\text { energy tools is required and a procurement system needs to be developed to adapt social } \\
\text { sustainability into the project. }\end{array}$ \\
\hline Bynum et al. (2013) & $\begin{array}{l}\text { Survey to determine the perceptions of the } \\
\text { use of BIM for sustainable design and } \\
\text { construction among designers and } \\
\text { constructors. }\end{array}$ & $\begin{array}{l}\text { Results indicate that most of the respondents believed that sustainability is not the main } \\
\text { BIM feature and project coordination and visualisation are more important. Despite this, } \\
\text { most of them believed that BIM will be vital in the future for achieving sustainable design } \\
\text { and construction. }\end{array}$ \\
\hline Inyim et al. (2014) & $\begin{array}{l}\text { A REVIT extension called SimulEICon was } \\
\text { introduced to support the decision-making } \\
\text { process during the design stage of a } \\
\text { construction project. A case study was } \\
\text { used to demonstrate the use of the tool. }\end{array}$ & The results show several of the solutions generated by SimulEICon, promoted sustainability. \\
\hline Jalaei and Jrade (2015) & $\begin{array}{l}\text { A methodology integrating BIM with LEED } \\
\text { in Canada is presented. }\end{array}$ & $\begin{array}{l}\text { The methodology simplifies the LEED process by eliminating the documentation process } \\
\text { which is one of the biggest barriers of adopting green principles, saving time and effort } \\
\text { during this process. }\end{array}$ \\
\hline Lu et al. (2017) & $\begin{array}{l}\text { Critical review from } 1999-2016 \text { of BIM for } \\
\text { green buildings due to the lack of } \\
\text { consensus among practitioners and } \\
\text { researchers about BIM applications to } \\
\text { promote green buildings. }\end{array}$ & $\begin{array}{l}\text { Project phases, green attributes and BIM attributes important to understand BIM and } \\
\text { green linkage. } \\
\text { Integration of Lean construction, among others, to improve the limited capabilities BIM } \\
\text { has on the construction and operation phases is proposed. } \\
\text { The lack of studies focusing on this integration is highlighted }\end{array}$ \\
\hline
\end{tabular}


Table 4: Examples of lean and sustainability application

\begin{tabular}{|c|c|c|}
\hline Reference & Method & Result \\
\hline Carneiro et al. (2012) & $\begin{array}{l}\text { Development of a Lean Sustainability } \\
\text { interaction matrix based on the LEED } \\
\text { approach. }\end{array}$ & $\begin{array}{l}\text { Waste reduction and competitive advantage found as major interactions. LEED does not } \\
\text { allow the flexibility valued by Lean construction. LEED does not promote reduction in time } \\
\text { and costs. }\end{array}$ \\
\hline Koranda et al. (2012) & $\begin{array}{l}\text { Case study of two projects to assess the } \\
\text { difficulties of implementing both Lean } \\
\text { and Sustainability concepts. }\end{array}$ & $\begin{array}{l}\text { LS application leads to waste reduction. Sustainability and Lean requirements are different. } \\
\text { Sustainability based on LEED prioritises waste reduction in terms of materials and emissions } \\
\text { and focuses on environmental aspects. Lean focuses on reducing waste from materials and } \\
\text { operations focusing on the value stream of projects. }\end{array}$ \\
\hline Rosenbaum et al. (2014) & $\begin{array}{l}\text { Value stream mapping (VSM) was used as } \\
\text { a Green-Lean approach to evaluate both } \\
\text { environmental and production waste in } \\
\text { the execution stage of a construction } \\
\text { project }\end{array}$ & $\begin{array}{l}\text { The results show a VSM detailed application in a project, confirming the tool as a detector } \\
\text { of environmental and production waste. }\end{array}$ \\
\hline Ogunbiyi et al. (2014) & $\begin{array}{l}\text { Literature review and survey of industry } \\
\text { practitioners to investigate the } \\
\text { contribution of implementing Lean } \\
\text { construction techniques in sustainable } \\
\text { construction. }\end{array}$ & $\begin{array}{l}\text { Benefits of integrating Lean construction and Sustainability principles are found such as: } \\
\text { Improved process flow and productivity, waste reduction, value maximisation and } \\
\text { environmental quality. Lean tools were also identified to enable sustainability. }\end{array}$ \\
\hline Marhani et al. (2013) & $\begin{array}{l}\text { Literature review on Lean construction, } \\
\text { highlighting implementation barriers. }\end{array}$ & $\begin{array}{l}\text { It is found that more holistic approaches are needed to adopt Lean construction such as } \\
\text { health and safety, six sigma and environmental management systems (EMS). This last } \\
\text { approach would maximise customer's satisfaction and reduce waste, enhancing } \\
\text { sustainability. }\end{array}$ \\
\hline AlSehaimi et al. (2014) & $\begin{array}{l}\text { Implementation of the Last Planner } \\
\text { System (LPS) in two construction projects } \\
\text { to improve planning and site } \\
\text { management. }\end{array}$ & $\begin{array}{l}\text { Results show sustainability synergies such as improved construction planning, enhanced } \\
\text { site management and better communication and coordination between the parties } \\
\text { involved. }\end{array}$ \\
\hline
\end{tabular}



Table 5: Summary of CSFs for BLS implementation.

\begin{tabular}{|c|c|c|}
\hline CSFs & B $\quad$ L $\quad S$ & Ref \\
\hline Collaboration & $\bullet \bullet \bullet$ & $1,6,13,14$ \\
\hline Visualisation & & 1 \\
\hline Coordination & $\bullet \bullet \bullet$ & $1,2,7,14$ \\
\hline Information exchange & $\bullet$ & $1,6,15$ \\
\hline Safety & $\bullet \quad \bullet$ & $1,4,15$ \\
\hline Leadership & $\bullet \quad \bullet$ & $2,3,4,5,6,7,8,13$ \\
\hline Training & $\bullet \bullet \bullet$ & $2,3,4,6,7,9-12,14$ \\
\hline Early involvement & $\bullet \bullet \bullet$ & $2,7,14$ \\
\hline Interoperability & $\bullet$ & $3,4,6$ \\
\hline Data security & $\bullet$ & 3 \\
\hline User interface & $\bullet$ & 3 \\
\hline Communication & $\bullet$ & $3,4,13$ \\
\hline Standardisation & $\bullet$ & $3,4,6$ \\
\hline Ownership & $\bullet$ & 3,4 \\
\hline Commitment & $\bullet \bullet \bullet$ & $3,4,7,9-13,15,18$ \\
\hline Qualified staff & $\bullet \bullet \bullet$ & $5,6,8,14,15$ \\
\hline Availability of information and technology. & $\bullet$ & 5 \\
\hline Investment & $\bullet$ & 5 \\
\hline Alternate procurement & $\bullet$ & 7 \\
\hline Adoption of new construction technologies/method & $\bullet$ & 7 \\
\hline Organisation culture & $\bullet \bullet \bullet$ & $3,4,6,7,8,13,15$ \\
\hline Teamwork culture & $\bullet \bullet$ & 7,15 \\
\hline Continuous improvement adoption & $\bullet$ & 7 \\
\hline Policies & $\bullet$ & 15,16 \\
\hline Clearly defined goals & $\bullet$ & 15,17 \\
\hline Environmental considerations & $\bullet$ & 15,16 \\
\hline Project monitoring and feedback & $\bullet$ & 15 \\
\hline Awareness & $\bullet$ & 16,17 \\
\hline \multicolumn{3}{|c|}{$\begin{array}{l}\text { 1. Antwi-Afari et al. (2018); 2. Liao and Teo (2017); 3. Shang and Shen (2014); 4. Yaakob et al. } \\
\text { (2016); 5. Ozorhon and Karahan (2016); 6. Won et al. (2013); 7. Sarhan et al. (2016); 8. Achanga } \\
\text { et al. (2006); 9. Brady and Allen (2006); 10.Marodin and Saurin (2013); 11. Nitin et al. (2011); } 12 \\
\text { Sila and Ebrahimpour (2003); 13. Laureani and Antony (2012); 14. Olawumi and Chan (2018); } 15 \\
\text { Banihashemi et al. (2017); 16. Sfakianaki (2018); 17. Liu et al.(2017); 18. Kiani Mavi and Standing } \\
\text { (2018) }\end{array}$} \\
\hline
\end{tabular}


Table 6: Existing BIM, lean and sustainability frameworks.

\begin{tabular}{|c|c|c|c|}
\hline Reference & Type & Industry & Main Contribution \\
\hline Khanzode et al. (2006) & $\begin{array}{l}\text { Conceptual B/L } \\
\text { framework }\end{array}$ & Construction & $\begin{array}{l}\text { Virtual design and construction (VCD) improve the Lean project delivery system (LPDS) when } \\
\text { applied at the correct stages. Guidelines on linking BIM and Lean construction are proposed. }\end{array}$ \\
\hline Toledo et al. (2016) & $\begin{array}{l}\text { B/L planning } \\
\text { framework }\end{array}$ & Construction & $\begin{array}{l}\text { Last Planner System (LPS) and BIM generates an increase in Percentage plan completed (PPC), a } \\
\text { decrease in reasons for non-compliance, a shortening of the meeting durations, and a decrease } \\
\text { in the total number of design requests for information (RFIs.) }\end{array}$ \\
\hline Alwan et al. (2017) & $\mathrm{B} / \mathrm{S}$ framework & Construction & $\begin{array}{l}\text { Ineffective strategies, policies and leadership have prevented full exploitation of the potential } \\
\text { of BIM and modern methods of construction (MMC) towards sustainable production. }\end{array}$ \\
\hline $\begin{array}{l}\text { Nascimento et al. } \\
\text { (2017) }\end{array}$ & $\mathrm{B} / \mathrm{L}$ methodology & Construction & $\begin{array}{l}\text { Methodology to improve the production planning and control of pipe-rack modules. Results } \\
\text { show improvements in prefabrication and preassembly planning. Reductions in welding-time. }\end{array}$ \\
\hline Ilhan and Yaman (2016) & $\begin{array}{l}\text { IFC based B/S } \\
\text { framework }\end{array}$ & Construction & $\begin{array}{l}\text { Results show that the proposed tool can be automatically process green data for BREEAM } \\
\text { certification which can be used to aid the design process. }\end{array}$ \\
\hline Ng et al. (2015) & L/S methodology & Metal & $\begin{array}{l}\text { Integration of Lean and Green manufacturing by introducing a metric called Carbon Value } \\
\text { Efficiency to integrate L/S implementation metrics. }\end{array}$ \\
\hline Gan et al. (2018) & B/S framework & Construction & Sustainable low carbon design of high-rise buildings is improved \\
\hline Banawi and Bilec (2014) & L/S framework & Construction & $\begin{array}{l}\text { Two types of waste were identified: Materials and time. "Changes in design during construction" } \\
\text { was identified as a potential cause for waste. }\end{array}$ \\
\hline Mollasalehi et al. (2018) & $\mathrm{B} / \mathrm{L}$ maturity model & Construction & Performance of projects implementing BIM and Lean is assessed and analysed. \\
\hline Wong and Wong (2014) & L/S framework & Manufacturing & Model promoting human integration in sustainable operations. \\
\hline
\end{tabular}


Table 7: Impacts of BLS in performance.

\begin{tabular}{|c|c|c|c|c|c|c|c|c|c|c|c|c|c|c|c|c|c|c|c|}
\hline & \multicolumn{19}{|c|}{ Reference } \\
\hline KPI & 1 & 2 & 3 & 4 & 5 & 6 & 7 & 8 & 9 & 10 & 11 & 12 & 13 & \begin{tabular}{|l}
14 \\
\end{tabular} & \begin{tabular}{|l|}
15 \\
\end{tabular} & 16 & 17 & 18 & 19 \\
\hline Quality & $B$ & $B$ & & & $\mathrm{~B}$ & & & & $\mathrm{~L}$ & & & & & & & & & $S$ & $\mathrm{~S}$ \\
\hline Safety & $\mathrm{B}$ & & & $\mathrm{B}$ & & & & & & $\mathrm{L}$ & & & & & & & $\mathrm{S}$ & $\mathrm{S}$ & \\
\hline Cost & $\mathrm{B}$ & & $\mathrm{B}$ & & $\mathrm{B}$ & & $\mathrm{L}$ & & $\mathrm{L}$ & & $\mathrm{L}$ & & & & & & & $\mathrm{S}$ & $\mathrm{S}$ \\
\hline Communication & & & & & $\mathrm{B}$ & $\mathrm{B}$ & & & & & & & & & & & & & \\
\hline Time & $\mathrm{B}$ & $\mathrm{B}$ & & & $\mathrm{B}$ & & & & & & & $\mathrm{L}$ & & & & $\mathrm{L}$ & & & \\
\hline Coordination & & & & & $\mathrm{B}$ & $B$ & & & & & & & & & & & & & \\
\hline Productivity & $\mathrm{B}$ & & $\mathrm{B}$ & & & & $\mathrm{L}$ & & & & & & $\mathrm{L}$ & $\mathrm{L}$ & & & & & $S$ \\
\hline Construction speed & & & & & & & $\mathrm{L}$ & & $\mathrm{L}$ & & & & & & & & & & \\
\hline Schedule & & & & & & & $\mathrm{L}$ & & & $\mathrm{L}$ & & & & & & & & & \\
\hline Waste & & & & & & & & $\mathrm{L}$ & $\mathrm{L}$ & $\mathrm{L}$ & & & & & & & & & \\
\hline Lead time reduction & & & & & & & & $\mathrm{L}$ & & & & & & & & & & & \\
\hline Value & & & & & & & & & $\mathrm{L}$ & & & & & & & & & & \\
\hline $\begin{array}{l}\text { Customer } \\
\text { satisfaction }\end{array}$ & & & & & & & & & & $\mathrm{L}$ & & & & & & & & & \\
\hline Planning & & & & & & & & & & $\mathrm{L}$ & & & & & & & & & \\
\hline Efficiency & & & & & & & & & & & & & & $\mathrm{L}$ & & & & & \\
\hline Cost effectiveness & & & & & & & & & & & & & & $\mathrm{L}$ & & & & & \\
\hline $\begin{array}{l}\text { Production } \\
\text { performance }\end{array}$ & & & & & & & & & & & & & & & L & & & & \\
\hline Air and water quality & & & & & & & & & & & & & & & & & $\mathrm{S}$ & & \\
\hline $\begin{array}{l}\text { Energy and water } \\
\text { consumption }\end{array}$ & & & & & & & & & & & & & & & & & $\mathrm{S}$ & $S$ & \\
\hline Waste disposal & & & & & & & & & & & & & & & & & $\mathrm{S}$ & & \\
\hline Health & & & & & & & & & & & & & & & & & $\mathrm{S}$ & $S$ & \\
\hline Energy management & & & & & & & & & & & & & & & & & & $\mathrm{S}$ & \\
\hline Profitability & & & & & & & & & & & & & & & & & & $S$ & $S$ \\
\hline $\begin{array}{l}\text { Stakeholder } \\
\text { satisfaction }\end{array}$ & & & & & & & & & & & & & & & & & & $S$ & \\
\hline $\begin{array}{l}\text { Innovation and } \\
\text { improvement }\end{array}$ & & & & & & & & & & & & & & & & & & $S$ & \\
\hline $\begin{array}{l}\text { Business } \\
\text { enhancement. }\end{array}$ & & & & & & & & & & & & & & & & & & & $S$ \\
\hline $\begin{array}{l}\text { 1. Suermann and Issa, } \\
\text { et al. (2016), Malekita } \\
\text { Alarcón et al. (2008); } \\
\text { (2005); 11. Nowotarsk } \\
\text { Ochoa (2014); 16. Ero } \\
\text { (2007) }\end{array}$ & $\begin{array}{l}\text { et a } \\
\text { et al }\end{array}$ & $\begin{array}{l}\text { lera } \\
(20 \\
(20\end{array}$ & $\begin{array}{l}\text { Elm } \\
201 \\
\text { et a } \\
16) ; \\
17) ;\end{array}$ & $\begin{array}{l}12.1 \\
17 . \mathrm{C}\end{array}$ & $\begin{array}{l}\text { lol, } \\
\text { ssa ( } \\
\text { gun }\end{array}$ & . & $\begin{array}{l}\text { i) } \\
\text { t al }\end{array}$ & (201 & $\begin{array}{l}012 \\
\text { 4); } 1\end{array}$ & $\begin{array}{l}10 \\
\text { 8. } \mathrm{X}\end{array}$ & $\begin{array}{l}\text {. }(20 \\
\text { et a }\end{array}$ & $\begin{array}{l}\text { khtar } \\
03) ; 1 \\
\text { I. (20 }\end{array}$ & $\begin{array}{l}\text { ret a } \\
\text { 14. M } \\
\text { 12); } 1\end{array}$ & $\begin{array}{l}\text { eo et } \\
13) ; 6 \\
\text { I. }(20 \\
\text { lao a } \\
\text { 19. Al }\end{array}$ & $\begin{array}{l}\text { al. (2 } \\
\text {. Faz } \\
15), \\
\text { nd Zh } \\
\text { bidin }\end{array}$ & $\begin{array}{l}\text { Salem } \\
\text { lang } \\
\text { and } P\end{array}$ & $\begin{array}{l}4 . \mathrm{H} \\
\text { I. }(20 \\
\text { et a } \\
2008 \\
\text { asqu }\end{array}$ & $\begin{array}{l}\text { ongli } \\
14) ; \\
\text { l. } \\
\text {; } 15 \\
\text { iire }\end{array}$ & \\
\hline
\end{tabular}


Table 8: BLS tools and methods.

\begin{tabular}{|c|c|c|c|c|c|c|c|c|c|c|c|c|}
\hline \multirow[b]{2}{*}{ Ref. } & \multirow[b]{2}{*}{ Tool/Method } & \multicolumn{11}{|c|}{ Characteristic } \\
\hline & & $\begin{array}{l}\text { Energy/ } \\
\text { thermal }\end{array}$ & $\begin{array}{c}\text { Lighting/ } \\
\text { shading }\end{array}$ & $\begin{array}{c}\text { Value/ } \\
\text { Cost }\end{array}$ & Acoustic & Modelling & $\begin{array}{c}\text { Clash } \\
\text { detection }\end{array}$ & Scheduling & $\begin{array}{l}\text { Quantity } \\
\text { takeoff }\end{array}$ & $\begin{array}{c}\text { Cost } \\
\text { estimating }\end{array}$ & $\begin{array}{c}\text { Waste } \\
\text { detection }\end{array}$ & $\begin{array}{l}\text { Waste } \\
\text { response }\end{array}$ \\
\hline 1 & Ecotect & BS & BS & & BS & & & & & & & \\
\hline 1 & GBS & BS & BS & BS & & & & & & & & \\
\hline 1 & IES VE & BS & BS & BS & & & & & & & & \\
\hline 2 & Revit & & & & & $\mathrm{BL}$ & & & & & & \\
\hline 2 & ArchiCAD & & & & & $\mathrm{BL}$ & & & & & & \\
\hline 2 & Vectorworks & & & & & $\mathrm{BL}$ & & & & & & \\
\hline 2 & Navisworks & & & & & & $\mathrm{BL}$ & $\mathrm{BL}$ & $\mathrm{BL}$ & & & \\
\hline 2 & Solibri Model Checker & & & & & & $\mathrm{BL}$ & & & & & \\
\hline 2 & BIMSight. & & & & & & $\mathrm{BL}$ & & & & & \\
\hline 2 & Sigma estimates. & & & & & & & & $\mathrm{BL}$ & $\mathrm{BL}$ & & \\
\hline 2 & Vico systems. & & & & & & & & & $\mathrm{BL}$ & & \\
\hline 3 & Value stream mapping (VSM) & & & & & & & & & & LS & \\
\hline 3 & Last planner system (LPS) & & & & & & & & & & & LS \\
\hline 3 & $5 S$ & & & & & & & & & & & LS \\
\hline 3 & Just in Time (JIT) & & & & & & & & & & & LS \\
\hline 3 & Concurrent engineering & & & & & & & & & & & LS \\
\hline 3 & Huddle meetings & & & & & & & & & & & LS \\
\hline \multirow[t]{3}{*}{3} & Total quality management (TQM). & & & & & & & & & & & LS \\
\hline & \multicolumn{12}{|c|}{ 1: Azhar et al. (2009); Azhar and Brown (2009); Wong and Fan (2013) } \\
\hline & $\begin{array}{l}\text { 2: Arayici et al. (2011); Bouška ( } 20 \\
\text { 3: Koskela (1992); Salem et al. (20) }\end{array}$ & $\begin{array}{l}\text {; Eastn } \\
\text {; Seppa }\end{array}$ & $\begin{array}{l}\text { et al. }(2 \\
\text { n et al. }(2\end{array}$ & 8); Liu & $\begin{array}{l}\text { al. }(201 \\
l \text { and } Y a\end{array}$ & 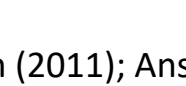 & (2. & & & & & \\
\hline
\end{tabular}




\section{Introduction}

The rise in information and communication technologies (ICT) and its benefits have been used as a way to respond to the complex nature of the construction industry $(\mathrm{Cl})$ and the effects on performance. This rise in ICT for the construction industry has been reflected in the development of Building Information Modelling (BIM) as the new Computer Aided Design paradigm (Succar, 2009), which can contribute to reduction of costs and errors (Bryde et al., 2013) and as an enabler for performance improvements. The BIM trend has increased over the past years. A review study from Abdal Noor and Yi (2018) on BIM in the $\mathrm{Cl}$ found that most of the research in this topic comes from the USA with 786 articles on the topic, followed by China, the UK, South Korea, Australia, Germany, Canada, Taiwan, Italy and Finland. From those articles, the diversity on the topics researched is vast confirming the range of possibilities of the BIM domain and most of the research were carried out by universities. Barlish and Sullivan (2012) measured the benefits of BIM implementation based on the investments and returns of BIM utilisation with positive results. A study on the same topic with similar results were also conducted by Giel and Issa (2013). Chen et al. (2014) analysed the level of maturity of BIM implementation by analysing key factors for measuring BIM maturity in construction projects. Liu et al. (2010), analysed the factors influencing the adoption of BIM in the AEC industry grouping them in three categories namely perceived benefits, external forces and internal readiness. A different study by Du et al. (2014) proposed a benchmarking application to automatically collect BIM performance data from BIM users to allow companies applying BIM, comparing their performance against best practice. BecerickGerber and Rice (2010) performed a survey to determine the perceived value of BIM in the American building industry focusing on benefits and costs regarding BIM use at the project 
level and concluding that BIM use is still at early stages and the true value of BIM application is yet to be achieved. Won et al. (2013) analysed critical success factors for BIM implementation obtained from international experts. A different approach of BIM analysing retrofitting strategies was studied by Hammond et al. (2014) to promote sustainability. Similarly, Zhou and El-Gohary (2018) also studied BIM to promote sustainability looking at regulatory information on energy codes. Other examples of BIM application include Moreno et al. (2019) on BIM in education facilities, Chen et al. (2018) and Boroujeni and Han (2017) on BIM in construction performance. Finally, more technical applications of BIM include earthquake assessment (Anil et al., 2015), laser scanning (Xiong et al., 2013), digitisation of existing buildings (Mellado et al., 2020) and application in other areas such as the mechanical construction industry (Boktor et al., 2014).

Similarly, lean principles have been applied to the $\mathrm{Cl}$, aiming to reduce waste and improve construction processes (Koskela, 2000). Waste has negative impacts on the environment and leads to poor efficiency. Concepts such as waste-to-resource and waste-to-energy have appeared as a better solution towards waste, however, it also generates added issues to the environment and leads to extra project costs (Pan et al., 2015). Lean construction has also increased its implementation and use over the past years. A review study from Babalola et al. (2019) found that the leading countries in the lean construction area are the USA, the UK and Brazil. Notable works in this field include Howell (1999) on concepts lean construction, Ballard (2000) on the development of The Last Planner System of Production Control, Koskela et al. (2002) on the foundations of lean construction and Ballard et al. (2002) on lean construction tools and techniques. Whelton et al. (2002) proposed a knowledge management framework for project definition of capital facility projects based on lean principles Zimina et al. (2012) introduced the target value design concept to reduce construction cost by applying 
collaboration and lean approaches. Hamzeh (2009) studied the improvement of lookahead planning and other Last Planner System indicators. Most recently, lean construction has been integrated with other practices such as BIM due to its synergistic nature of improving construction processes and reducing waste (Nguyen and Akhavian, 2019).

Research has demonstrated that improvements in the operational, technological and cleaner production fields are still unexplored in the $\mathrm{Cl}$ (Saieg et al., 2018). There is great potential to increase productivity and efficiency that are related with BIM and lean goals, whilst also improving sustainability. However, there are few studies focusing on this aspect and there are no frameworks suggesting an integrated management framework. Koskela et al. (2010) and Enache-Pommer et al. (2010) suggested synergies between BLS and most recent developments on the field have been made by authors such as Ahuja et al. (2016) and Saieg et al. (2018) but the application on real scenarios remains a challenge and barriers are still under exploration. In this sense, the benefits of full BIM adoption are still unexplored (Walasek and Barszcz, 2017) and the slow adoption of lean is a major hurdle (Djokoto et al., 2014) and sustainability in the construction industry is still focused on the environmental and economic part, neglecting the social aspect (Det Udomsap and Hallinger, 2020). Therefore, reaching for a balance is still an important barrier for wider adoption. Organisations in the $\mathrm{Cl}$ have the opportunity of changing the way on how they conduct their businesses by integrating BLS practices into their core because it essential to count with their commitment to adopt BLS for the integration to be successful. The synergistic nature of the aspects under study can provide opportunities for improvements and an even stronger synergy when integrated by committing the entire organisation as a starting point. 
The aim of this study is to research, analyse and articulate existing work on BIM, lean and sustainability to study the elements that would compose an initial conceptual framework aiming to integrate $\mathrm{BIM}$, lean and sustainability (BLS) to promote performance improvements. The linkage among these three aspects has been suggested but not presented as an integrated framework to demonstrate specific components for their integration. This study structure starts with background on performance in the $\mathrm{Cl}$ and how it is related with BIM, lean and sustainability principles. Next, the research method is explained and the proposed framework's components such as drivers and barriers, existing frameworks and models, critical success factors (CSFs), integrated project delivery (IPD), impacts of BLS on project performance, are discussed. Finally, research gaps and conclusions are presented. The main contribution of this study is to provide an alternative trichotomy of a BIM-LeanSustainability (BLS) framework to promote performance improvements in the $\mathrm{Cl}$.

\section{Research background}

Performance in the $\mathrm{Cl}$ has been a common topic among practitioners; despite evolution of the $\mathrm{Cl}$, projects are still failing to meet success criteria. Traditionally, performance is viewed as meeting quality, time and cost constraints, also known as the 'Iron Triangle'. However, these success measures are being criticised as new projects are becoming more complex to manage to be only measured by the traditional three parameters (Mellado et al., 2019); similarly, other aspects have also been considered but they have mainly been used for benchmarking purposes but not to control project performance (Toor and Ogunlana, 2010). In this sense, including other aspects to assess performance means in the near future, projects may be measured based on different criteria according to the construction industry evolution 
such as government's plans for BIM and carbon emissions reduction and how these impact on performance evaluation (Edwards et al., 2019). Major changes related to innovation and collaboration, have been occurring aiming to improve productivity, efficiency and sustainability such as digitalisation in the form of BIM that is considered an innovation tool to achieve efficiency and improved communication which is set to become an integration enabler to adopt other practices due to its synergistic nature with performance improvements (Horta et al., 2010).

Construction projects are by their nature complex, consequently, effective management linked with successful integration of tools and methodologies is crucial to comply with project requirements. Collaboration and communication are key to promote improvements and the lack of them is regarded as one of the main reasons that construction projects still fail. By adopting integrated approaches project outcomes can be improved, and improved overall performance can also be achieved. Efforts have been made by practitioners to study and analyse effective integration of management concepts; for example, a study by Demirkesen and Ozorhon (2017) on integration management and its impact on performance demonstrated a lack of a comprehensive understanding between these two concepts which are crucial in the successful management of construction projects, and also, suggested the integration of different methodologies and tools in different construction project phases such as BIM and lean principles. The study, concludes that integration of practices is a key element of successful project performance and that the $\mathrm{Cl}$ is still in search of effective practices and strategies. As a result, there are some studies proposing integrating BIM, lean and sustainability in pairs or in isolation (Sacks et al., 2010; Mahalingam et al., 2015; Tauriainen et al., 2016). However, comprehensive frameworks are still missing. For these reasons, it is 
hypothesised in this study that by adopting an integrated approach of these three major drivers, construction projects would be more efficient throughout their life cycle because project stages are strengthened. BIM processes have been accepted as an enabler by the $\mathrm{Cl}$ to improve performance through the project life cycle, but they have not yet reached their full potential. At the operational phase, lean methodologies are used to produce safer, faster and cost-effective projects due to its aim of reducing waste and maximise effectiveness. Furthermore, the $\mathrm{Cl}$ has targeted the reduction of carbon emissions and to become more environmentally friendly (UKGBC, 2017), which is synergistic with what BIM and lean principles promote. The final outcome is to produce a product which complies with the standard of time, cost and quality but also considering the environment and the process on how the final outcome is reached. Thus, by proposing and integrated approach, the performance of projects and the industry can be improved (Mellado et al., 2019). The exploration of BIM, lean practices and sustainability in terms of performance, synergies, and integration as a single approach is still in early stages, therefore more research needs to be carried out in this area (Saieg et al., 2018).

\section{Research method}

The aim of this study is to explore the theoretical integration of three current relevant areas to the evolution of the construction process to deliver more efficient and sustainable projects throughout their entire lifecycle, on the belief that these would achieve synergies when integrated, thereby reaching increased levels of performance. The first objective is to identify and evaluate the current state of the literature related to BIM, lean and sustainability to later classify the articles found to identify gap areas and opportunities for new research. This 
approach is taken to achieve a better understanding of new topics (Easterby-Smith et al., 2002); and to structure the information which will be used to propose a BLS framework. The literature step is of utmost importance to establish the current state of relevant knowledge and to discover new areas that need further development (Webster and Watson, 2002). This structured process is carried out to obtain an effective literature review and it is done by defining the unit of analysis, classification of the context, evaluation of material and publications collection and field delimitation (Saunders et al., 2008).

Insert Table 1 and figure 1

The literature search that was conducted covered the period from 2000 to 2018 to represent the proposed ideas in the new era of construction after the report presented by Egan (1998) proposing a new way of working in the $\mathrm{Cl}$ and the start of a new century. Furthermore, a new production paradigm presented by Koskela (2000) has become more matured since it was first mentioned in 1992.

Insert figure 2 and 3

Figure 2 and 3 demonstrates the distribution per year of each individual driver and their synergies to show the analysis per year throughout the entire period under study, starting from 2000 onwards and the first relevant paper within the scope of this research was found in 2001. There has been a clear increase in journal papers being published in the three areas of interest, however, research into their comprehensive integration as proposed in this research appears to be non-existent so far. 
Insert figure 4

The research streams as presented in Figure 4 show that the majority of the papers are related to BIM in isolation (28\%), followed by sustainability $(16 \%)$ and lean $(15 \%)$ whilst the synergies between the three drivers are very low (2\%). From this analysis, it can be deduced that BIM is growing in importance because it has reached an appropriate level of maturity and acceptance by the industry which could be caused by the requirements set by governments among other benefits encountered. The other drivers, especially lean, have decreased in terms of published research. However, the combination in pairs such as lean/sustainability (LS), BIM/sustainability (BS) and BIM/lean (BL) are still an important part of research.

\section{Proposed conceptual framework}

A conceptual combination is proposed, aiming to promote performance improvements in the construction industry. This proposed framework is also intending to create a system in which continuous improvement could be reached in a well organised and efficient way. The literature suggested that the same restrictions on lean and sustainability when considered in isolation have been encountered when integrating them (Cherrafi et al., 2016). The proposition of including BIM with lean and sustainability should overcome this issue as they are complementary (Ahuja et al., 2016); thus, each strategy is capable of reducing the limitations of the others. 
The framework considers the reasons for adoption (drivers), as well as barriers (for instance, cultural and technological) that can affect integration. The proposition is that organisations in the $\mathrm{Cl}$ should consider the BLS integration aiming to improve efficiency, environmental, economic and social performance of their construction activities with BIM methodologies as a catalyst. In addition, the potential barriers that could prevent integration need to be assessed for this process to successfully work. As the framework is intended to be applicable in general terms, cultural and technological aspects could be considered as potential barriers; for example, training and education could be an important factor, since implementing new management practices require a level of knowledge prior to the implementation in systematic routines and working practices (Blackler, 1995). Setting a new integrated framework would bring expected benefits and synergies which can be measured through the common indicators adopted by the industry related to BLS. Similarly, integrating complex practices could lead to potential issues which are prevented by including specific tools, methods and techniques which if not considered, successful implementation could be affected, causing limitations (Cherrafi et al., 2016). For example, sustainability has its own complexities in terms of processes, making it different to traditional construction practices (Ansah et al., 2019).

The proposed framework components would be based on criteria found in the European Foundation for Quality Management Excellence model (EFQM) which assesses both organisational and operational performance and it is one of the most popular frameworks along with the Balance Scorecard Sheet (Bassioni et al., 2005). The reason for using the criteria from this model is that it allows a clear vision of both management and processes to be established and also because of their focus on performance in the long term. In this sense, it also allows a foundation for sustainable excellence considering the whole organisation and 
the ability to track and measure progress (Vukomanovic et al., 2014). The BSC model was not considered in this framework because of its over simplicity (Kagioglou et al., 2001). Lean focuses on waste identification and reduction, but it does not consider sustainability aspects therefore, several organisations have included sustainability in their practices to overcome this shortcoming (Ng et al., 2015). There are studies proposing the integration of lean and sustainability principles to help reduce unnecessary waste in environmental and social processes; however, organisations applying those concepts have not achieved top sustainability performance but the inclusion of BIM may help fulfil this goal. The resulting BLS framework is proposed to take advantage of the strong connections between the BIM (B), lean (L) and sustainability (S) management systems considering drivers, barriers and challenges and benefits of the integration. The arrows on the model show the strong connections between the framework elements that work combined as an integrated framework aiming to promote performance improvements in the $\mathrm{Cl}$, increasing efficiency and enhancing sustainability as well as identifying strengths and promoting continuous improvement.

\section{Insert Figure 5}

\section{Discussion of framework components}

\subsection{Integration drivers}

BLS implementation is motivated by drivers and barriers to their adoption; therefore prior to their integration, an assessment is required to ensure a proper evaluation. The analysis considers both internal and external drivers. 
There are shared internal and external drivers (Figure 6) (Kleindorfer et al., 2009). For example, costs of resources are frequently rising due to high demand, therefore, forecasting them may be difficult so accomplishing resource efficiency is necessary to obtain better performance results (Wong and Wong, 2014). It is acknowledged that sustainability principles must be in balance and each principle has the capacity of impacting the others. Similarly, the application of environmental drivers is viewed as an improvement of financial performance which is seen as brand image improvement (Wadhwa, 2014), therefore, organisations are looking to those aspects to positively impact in the market (King and Lenox, 2001). In this regard, improving environmental performance is positively viewed as part of corporate social performance (Pagell and $\mathrm{Wu}, 2009$ ). Companies of all sizes are driven by external forces to constantly evaluate and adapt their processes to improve their performance, also, people are more environmental aware which makes them consider more sustainable options (Xie et al., 2017). Social performance linked to sustainability is also a major consideration to banks, investors and shareholders, making it even more important to companies involved in the industry (Kadry, 2013). In the case of BIM, Eadie et al. (2013b) reported that non-BIM users consider government pressure, competitive and client pressure as the most important drivers, whereas, BIM users classified those same drivers at the bottom of their priorities. BIM users found that clash detection, cost savings through reduced rework and improving design quality are the most important drivers for adoption. 


\subsection{Integration barriers and challenges}

Walasek and Barszcz (2017), suggest that the full application of BIM has not been exploited yet which can lead to problems of trust and difficulties in the adoption. Other challenges include the cost of adoption, learning curve and individual commitment that need overcoming if the application intends to be successful (Lee et al., 2015). According to Dave et al. (2016), communication frameworks that systematically tackle information flow requirements through the construction project lifecycle are still missing. In this sense, the integration of lean methodologies and ICT, such as BIM alongside with environmental outcomes would help overcome this issue by presenting a system considering the entire project lifecycle. However, adoption of lean practices itself has proven to be difficult (Sarhan and Fox, 2013). Despite these hindrances, organisations that have implemented lean are more likely to adopt environmental indicators (Mollenkopf et al., 2010).

\section{Insert Figure 7}

When considering the adoption of integrated lean construction and sustainable practices organisations have found the integration difficult despite the strong synergies between them and literature shows that the implementation has been poor and slow ( $\mathrm{Ng}$ et al., 2015; Djokoto et al., 2014); also sustainability driven projects are more complex than traditional methods due to more specialised and bespoke processes that lead to more complex construction (Ochoa, 2014). On the idea of sustainability integration with social and environmental aspects, Simboli et al. (2014) states that this idea will work only when there is a clear increase in economic value by organisations and the idea of improvement in 
environmental and social performance is still believed to be a hurdle in achieving economic growth (Fond, 2009).

\subsection{Interactions benefits}

Gains in efficiency, waste reduction, added value, rework reduction and performance improvement in projects are some of the reported benefits of BIM, which are directly related to lean principles (Table 2). Improved flow and overall time reduction by applying clash detection, visualisation and collaborative planning are practical benefits of the BIM contribution towards lean goals. Table 2 shows examples of BIM and Lean applications confirming the strong synergy between these two methodologies.

\section{Insert Table 2}

Similarly, the construction industry worldwide is under pressure not only to reduce waste and to increase low levels of material recycling (Liu et al., 2011), but also to comply according to specific environment requirements established by governments and by international treaties. For example, the UK government has set out specific targets for new domestic and commercial buildings to reduce carbon emissions (Heffernan et al., 2015); these targets have arisen as a need to comply with successive Energy in Buildings Directives and associated legislation. In this respect, BIM methodologies are established as a catalyst for change, with sustainability improvement being a major benefit obtained from its application. Table 3 shows some examples of BIM and sustainability applications, confirming the strong synergy between these two methodologies. 
Insert Table 3

In recent years, BIM and sustainability practices have been growing and have been adopted in the built environment (Wong and Kuan, 2014); because the $\mathrm{Cl}$ is urged to adopt sustainable strategies to tackle the existing concerns regarding $\mathrm{CO}_{2}$ emissions and dependency on fossil fuels, being the use of BIM methods a powerful tool that allows the use of the design data for both sustainable design and performance analysis (Wu and Issa, 2015). Efforts have been made in studying BIM to promote sustainability outcomes in areas such as energy performance simulation, lighting analysis, construction and demolition waste analysis (Lu et al., 2017). Most of the studies focus on the development of applications to integrate sustainability analysis into design, construction and operation processes. Different management aspects of BIM adoption and sustainability have also been studied, such as economic benefits and organisational adoption barriers. Lean and sustainability are usually two separate and independent concepts targeting to improve economic standards and environmental objectives, respectively. Even though this difference in objectives exists, both share the same goals, mainly towards waste reduction, resource optimisation and process improvement which make them to a significant extent interdependent (Al-Aomar and Weriakat, 2012), therefore, maximising performance and enhancing construction not only in economic aspects, but also in social and environmental terms is of major importance (Abreu et al., 2017). The main advantage of applying lean principles is their ability to identify waste as well as other benefits such as shortened lead times, reduced material waste, quality improvement, reduced carbon emissions and improved value chain which can be accrued by LS integration (Peng and Pheng, 2010). Table 4 shows some examples of Lean and 
Sustainability application which illustrate the strong synergy between these two methodologies and hence, their potential for integration

\section{Insert Table 4}

\subsection{Critical success factors (CSFs) for implementing BLS}

The integration of BLS is a complex process whose considerable potential benefits are not easy to accomplish. Thus, identifying critical success factors (CSFs) is an important part of the framework since they give an outlook on the efforts that need to be taken to increase the chance of successful implementation and identify areas for further improvement (Lou and Alshawi, 2009).

\section{Insert Table 5}

From Table 5 it could be said that the CSFs deal with human and management aspects rather than technical issues. According to Shub and Stonebraker (2009) these aspects (Human resource management, top management support and leadership, people involvement, teamwork, training and education, as well as culture and communication) are important since they are more regenerative and enduring as competitive advantages. The BLS framework should consider the same CSFs since the three components could be considered as complex management systems, therefore, depending on the type of industry, their CSFs are similar with strong attention on technological components which in this case would be the BIM aspect. However, validation is still required and proposed as a further research suggestion. 


\subsection{Integrated project delivery (IPD)}

A collaborative approach is required for the BLS framework to work such as integrated project delivery (IPD) which is a system that promotes collaboration by aligning incentives and project team goals through shared reward and risk and also promotes early involvement of the parties (Ma et al., 2018). The key is to establish clear contractual relationships as well as wellestablished project goals and team conformation from the beginning which are important features for IPD success. Other factors for IPD success are clear scope of works, well-defined roles, relationships and responsibilities (Kent and Becerik-Gerber, 2010). Therefore, it is seen that successful integration processes are in accordance with IPD.

\subsection{Existing frameworks and models}

Different models for integrating the approaches under study in isolation or in pairs have been found in the literature. In total, 16 models and frameworks were studied as shown in Table 6. In order to work properly, the models, frameworks, methodologies need active involvement from the organisation, leadership, people involvement and a certain maturity level regarding the BIM, lean and sustainability areas. Abreu et al. (2017) found that lean-sustainability (LS) models applied to the $\mathrm{Cl}$ are still missing in the literature and that there are few models integrating these two principles published from 2012 onwards and certainly none of those were related to the $\mathrm{Cl}$ The ones that indeed are related to the $\mathrm{Cl}$ had waste reduction as their main priority. The aim of the models found in the review was to improve productivity in their respective areas whilst reducing the impacts of their activities to the environment. In general, by integrating sustainable practices with lean principles is an approach which will yield a 
greener industry. Finally, it is established that the field of study is emerging due to the strong relationship between lean principles and sustainability, demanding an integrated approach. BS frameworks are mostly related to environmental analysis, BL models are emerging, but it was difficult to find papers from 2010 onwards analysing BIM other than the interactions described in previous sections.

\section{Insert Table 6}

\subsection{Impacts of BLS on project performance}

The interactions explained in previous sections show the strong synergies between BLS which on their own improve the performance of construction projects but with different emphasis depending at what stage of project life cycle they are applied.

\section{Insert Table 7}

BIM can be used throughout the entire project life cycle, in the planning stage, BIM allows potential reduction of waste and re-planning (Gibbs et al., 2015); design by improving coordination among project participants (Singh et al., 2011). The construction stage by forecasting project cost and schedule, reducing errors and omissions and improving productivity (Wang et al., 2014); Operations and maintenance stage by using a virtual environment to provide regular maintenance (Chong et al., 2014) and refurbishment and demolition by supporting the appropriate method for refurbishment and demolition (Yun et al., 2014). However, it is currently mostly used in the design stage of projects with less emphasis on later stages (Eadie et al., 2013a). Sustainability approaches are generally 
focused on the design and operation project stages, whereas lean principles are focused typically on the construction stage (Kurdve et al., 2015). By bringing them together in a unified system, the focus of improvement would be the entire project life cycle as a whole which would be the main advantage of combining them.

The use of materials is directly correlated with sustainability in the environmental dimension by simulating testing of materials in a 3D BIM environment tools are also used to perform energy simulation analysis such as heating conditions, ventilation, air conditioning and lighting. BIM, lean and sustainability have different tools that improve how construction projects are delivered. Table 8 shows a list of tools that contribute towards performance improvements. These tools are also a part of the proposed framework shown in figure 5. Tools and techniques nearly always require extra investment to implement and maintain them properly. Therefore, it is necessary that this return of effort is reflected in every dimension.

\section{Insert Table 8}

It is seen that each driver in isolation brings performance improvements which in an integrated approach would yield better project outcomes as proposed in the BLS theoretical framework. There are similarities in performance improvement from the drivers which suggest that integrating them does not result in conflicts from a performance improvement point of view. Current needs in terms of efficiency in the processes and environment make it necessary to adopt more productive and efficient systems to tackle the challenges the industry faces. The way these three drivers are seen is in terms of innovation in production (lean principles), product representation (BIM) and product requirements (sustainability) 
which promote collaboration. Therefore, by integrating and implementing them, combined benefits will be obtained and most importantly, the performance for the construction industry would improve as well as the quality of the constructed facilities, bringing benefits to both stakeholders and society.

\section{Research gaps}

Despite the importance of BIM, lean and sustainability for the $\mathrm{Cl}$ there is currently no published research on how the integration would benefit performance in projects. This paper is part of ongoing research where the framework has been established from the available literature, therefore the next logical step is validation. One of the main gaps is that every aspect of performance was researched individually. There have been improvements by applying BLS in projects as shown in the review but integrating management systems such as the ones proposed poses difficulties and complexities therefore, there is still an unknown outcome which is yet to be obtained.

Another gap is the lack of models and frameworks to compare the proposed BLS framework against. For example, in the sustainability model and frameworks are usually related to energy, neglecting the social aspect, therefore, there is no balance among the sustainability components, emphasising one over the others. The BL based models and frameworks are applied to specific contexts and scenarios and may not be applicable across different processes and project stages; thus, a more general view is still missing. In this sense, systematic frameworks and methodologies are needed which can be applied to real scenarios for validation and applicability assessment. This way, their constant feedback and improvement will be ensured. Most of the frameworks encountered are developed for 
specific purposes and their applicability is under those circumstances. Developing a validated integrated model is desirable.

It is suggested that the validation and application process is performed within the small organisations context since they are of utmost importance in the global economy, contributing to economic growth, employment and innovation. Furthermore, the challenge for those type of organisations is to comply with the industry requirements where BLS could play an important role to achieve success. The BIM, lean, sustainability adoption in isolation for small organisations is a major challenge, let alone in an integration manner mainly due to the different factors to be considered such as high cost and lack of reported benefits. It is important as well to promote integration at a stakeholder level which, from the review, is one of the most important aspects to consider when implementing new practices. Achieving a successful BLS integration and implementation is part of a successful social change within the industry, however, results showed a lack of social integration, therefore there is an unexplored area for research which needs a more comprehensive understanding. Finally, BLS integration could also bring negative effects that are yet to be explored.

\section{Conclusion}

$\mathrm{BIM}$, lean and sustainability are major current trends on its own that are being addressed by the $\mathrm{Cl}$ and recently it has been proposed that they work better when integrated rather than treated in isolation, however there are no comprehensive frameworks suggesting an integration. The starting point to understand this issue and fill this gap is by suggesting an integrated framework based on theoretical elements analysing different variables. A literature review of 215 journal papers published from 2000-2018 was carried out, and the 
results show that in terms of the interactions between BIM and lean the main focus is on waste reduction, between BIM and sustainability are the solutions focused on improving specific environmental aspects such as energy and lighting and between lean and sustainability the focus was on improving environmental aspects by reducing waste. Coordination, collaboration, training, early involvement, commitment, qualified staff and organisation culture were the shared critical success factors between BIM, lean and sustainability. Existing studies on BLS integration only accounted for a $2 \%$ out of the total papers reviewed. Finally, in terms of performance improvements the BLS components have great opportunities to improve individual KPIs but in an integrated manner BLS only share a few in theory. The limitation of this study is that the framework presented in this research was proposed as a conceptual integrated model which requires validation. To do so, a small sized enterprises approach is suggested. In this era where requirements such as BIM plans and sustainability goals are making organisations consider new ways of working to adapt to the evolving nature of the industry and the difficulties and challenges presented, this extra pressure to fulfil those requirements makes the adoption of a BLS framework a totally plausible scenario.

\section{Acknowledgement}

This research is supported by BECAS Chile (Folio 72170109), National Commission for Scientific and Technological Research (CONICYT), Ministry of Education, Chile. 


\section{References}

1. Abdal Noor, B., Yi, S. (2018). "Review of BIM literature in construction industry and transportation: meta-analysis", Construction Innovation, Vol. 18 No. 4, pp. 433-452.

2. Abidin, N.Z., Pasquire, C.L., 2007. Revolutionize value management: A mode towards sustainability. Int. J. Proj. Manag. 25, pp. 275-282.

3. Abreu, M.F., Alves, A.C., Moreira, F., 2017. Lean-Green models for eco-efficient and sustainable production. Energy 137, pp. 846-853.

4. Achanga, P., Shehab, E., Roy, R., Nelder, G., 2006. Critical success factors for lean implementation within SMEs. J. Manuf. Technol. Manag. 17, pp. 460-471.

5. Ahuja, R., Sawhney, A., Arif, M., 2016. Driving lean and green project outcomes using BIM: A qualitative comparative analysis. Int. J. Sustain. Built Environ. 6 (1), pp.69-80.

6. Al-Aomar, R., 2012. A lean construction framework with Six Sigma rating. Int. J. Lean Six Sigma 3, pp. 299-314.

7. Al-Aomar, R., Weriakat, D., 2012. A framework for a green and lean supply chain: a construction project application. Proc. 2012 Int. Conf. Ind. Eng. Oper. Manag. pp.289299.

8. Alarcón, L.F.L., Diethelm, S., Rojo, O., Calderón, R., 2008. Assessing the impacts of implementing lean construction. Rev. Ing. Constr. 23, pp. 26-33.

9. AlSehaimi, A.O., Tzortzopoulos, F., Koskela, L., 2014. Improving construction management practice with the Last Planner System: a case study. Eng. Constr. Archit. Manag. 21, pp. 51-64.

10. Alwan, Z., Jones, P., Holgate, P., 2017. Strategic sustainable development in the UK construction industry, through the framework for strategic sustainable development, using Building Information Modelling. J. Clean. Prod. 140, pp. 349-358. 
11. Anil, E.B., Akinci, B., Kurc, O., Garrett, J.H. (2015). Building-information-modelingbased earthquake damage assessment for reinforced concrete walls. J. Comput. Civ. Eng. (2015), p. 04015076.

12. Ansah, M.K., Chen, Xi., Yang, H., Lu, L., Lam, P.T.I. (2019). A review and outlook for integrated BIM application in green building assessment. Sust.Cities. 48, 101576.

13. Ansah, R.H., Sorooshian, S., Mustafa, S. Bin, Duvvuru, G., 2016. Lean Construction Tools. Proc. 2016 Int. Conf. Ind. Eng. Oper. Manag. Detroit, Michigan, USA, Sept. 2325, pp. 784-793.

14. Arayici, Y., Coates, P., Koskela, L., Kagioglou, M., Usher, C., O’Reilly, K., 2011. Technology adoption in the BIM implementation for lean architectural practice. Autom. Constr. 20, pp. 189-195.

15. Azhar, S., 2011. Building Information Modeling (BIM): Trends, Benefits, Risks, and Challenges for the AEC Industry. Leadersh. Manag. Eng. 11, pp. 241-252.

16. Azhar, S., Brown, J., 2009. BIM for sustainability analyses. Int. J. Constr. Educ. Res. 5, pp. 276-292.

17. Azhar, S., Brown, J., Farooqui, R., 2009. BIM-based Sustainability Analysis: An Evaluation of Building Performance Analysis Software. Proc. 45th ASC Annu. Conf, pp. $1-4$.

18. Babalola, O., Ibem, E.O., Ezema, I.C. (2019). Implementation of lean practices in the construction industry: a systematic review. Build. Environ., 148 (2019), pp. 34-43.

19. Ballard, G. (2000). The Last Planner System of Production Control. PhD thesis, Dept. of Civil Engineering, University of Birmingham, Birmingham, U.K., June 2000. 
20. Ballard, G., Tommelein, I., Koskela, L. and Howell, G. (2002). Lean Construction Tools and Techniques. Chapter 15 in Best \& de Valence (editors), Design and Construction: Building in Value. Butterworth-Heineman.

21. Banawi, A., Bilec, M.M., 2014. A framework to improve construction processes: Integrating lean, green and six sigma. Int. J. Constr. Manag. 14, pp. 45-55.

22. Banihashemi, S., Hosseini, M.R., Golizadeh, H., Sankaran, S., 2017. Critical success factors (CSFs) for integration of sustainability into construction project management practices in developing countries. Int. J. Proj. Manag. 35, pp. 1103-1119.

23. Barlish, K., Sullivan, K. (2012). "How to measure the benefits of BIM - a case study approach". Autom. Construct., 24 (2012), pp. 149-159.

24. Bassioni, H., Price, A., Hassan, T., 2005. Building a conceptual framework for measuring business performance in construction: an empirical evaluation. Constr. Manag. Eco. 23(5), pp. 495-507.

25. Becerick-Gerber, B., Rice, S. (2010). The perceived value of building information modeling in the U.S. building industry. ITcon, 15 (2010), pp. 185-201.

26. Blackler, F., 1995. Knowledge, Knowledge Work and Organizations: An Overview and Interpretation. Organ. Stud. 16, pp. 1021-1046.

27. Boktor, J., Hanna, A., Menassa, C. (2014). State of practice of building information modeling in the mechanical construction industry. J. Manag. Eng., 30 (1) (2014), pp. 78-85.

28. Boroujeni, K.A., Han, K. (2017). Perspective-Based Image-to-BIM Alignment for Automated Visual Data Collection and Construction Performance Monitoring. J. Comput. Civ. Eng. (2017), pp. 171-178 
29. Bouška, R., 2016. Evaluation of Maturity of BIM Tools across Different Software Platforms. Procedia Eng. 164, pp. 481-486.

30. Brady, J.E., Allen, T.T., 2006. Six Sigma Literature: A Review and Agenda for Future Research. Qual. Reliab. Eng. Int. 22, pp. 335-367.

31. Bryde, D., Broquetas, M., Volm, J.M., 2013. The project benefits of building information modelling (BIM). Int. J. Proj. Manag. 31, pp. 971-980.

32. Bynum, P., Issa, R.R.A., Olbina, S., 2013. Building information modeling in support of sustainable design and construction. Am. Soc. Civ. Eng. 139, pp. 24-34.

33. Caldera, H.T.S., Desha, C., Dawes, L., 2018. Exploring the role of lean thinking in sustainable business practice: A systematic literature review. J. Clean. Prod. 167, pp. 1546-1565.

34. Carneiro, S.B.M., Campos, I.B., De Oliveira, D.M., Neto, J.P.B., 2012. Lean and green: A relationship matrix. 20th Conf. Int. Gr. Lean Constr. IGLC 2012, July 17 - July 22, 2012.

35. Chen, Y., Dib, H., Cox, R. (2014). "A measurement model of building information modelling maturity", Construction Innovation, Vol. 14 No. 2, pp. 186-209.

36. Chen, Y., John, D., Cox, R. F. (2018). "Qualitatively Exploring the Impact of BIM on Construction Performance," in ICCREM 2018, Charleston, South Carolina, 2018, pp. $60-71$.

37. Cherrafi, A., Elfezazi, S., Chiarini, A., Mokhlis, A., Benhida, K., 2016. The integration of lean manufacturing, Six Sigma and sustainability: A literature review and future research directions for developing a specific model. J. Clean. Prod. 139, pp. 828-846.

38. Chong HY., Wang J., Shou W., Wang X., Guo J., 2014. Improving Quality and Performance of Facility Management Using Building Information Modelling. In: Luo Y. 
(eds) Cooperative Design, Visualization, and Engineering. CDVE 2014. Lecture Notes in Computer Science, vol 8683. Springer, Cham.

39. Chong, HY., Wang, X., Lee, CY., 2016. A mixed review of the adoption of Building Information Modelling (BIM) for sustainability. J. Clean. Prod. 142, pp. 4114-4126.

40. Dave, B., Boddy, S., Koskela, L., 2011. Visilean: designing a production management system with lean and BIM. 19th Annu. Conf. Int. Gr. Lean Constr. pp. 514-524.

41. Dave, B., Kubler, S., Främling, K., Koskela, L., 2016. Opportunities for enhanced lean construction management using Internet of Things standards. Autom. Constr. 61, pp. 86-97.

42. Demirkesen, S., Ozorhon, B., 2017. Impact of integration management on construction project management performance. Int. J. Proj. Manag. 35, pp. 1639-1654.

43. Det Udomsap, A.; Hallinger, P. (2020). A bibliometric review of research on sustainable construction, 1994-2018. J. Clean. Prod. 2020, 254, 120073.

44. Djokoto, S.D., Dadzie, J., Ohemeng-Ababio, E., 2014. Barriers to Sustainable Construction in the Ghanaian Construction Industry: Consultants Perspectives. J. Sustain. Dev. 7, 134-143.

45. Du, J., Liu, R., Issa, R. (2014). BIM cloud score: benchmarking BIM performance J. Construct. Eng. Manage., 140 (11) (2014), p. 04014054.

46. Eadie, R., Browne, M., Odeyinka, H., McKeown, C., McNiff, S., 2013a. BIM implementation throughout the UK construction project lifecycle: An analysis. Autom. Constr. 36, pp. 145-151.

47. Eadie, R., Odeyinka Henry, Mike Browne, C.M., Yohanis, M., 2013b. An Analysis of the Drivers for Adopting Building Information Modelling. J. Inf. Technol. Constr. 18, pp. $338-352$. 
48. Easterby-Smith, M., Thorpe, R., Lowe, A., 2002. Management Research: An Introduction. London: SAGE.

49. Eastman, C.M., Eastman, C., Teicholz, P., Sacks, R., Liston, K., 2008. BIM Handbook: A Guide to Building Information Modeling for Owners, Managers, Designers, Engineers and Contractors. Wiley.

50. Edwards, R., Lou, E.C.W., Bataw, A., Kamaruzzaman, S.N. and Johnson, C. (2019), "Sustainability-led design: Feasibility of incorporating whole-life cycle energy assessment into BIM for refurbishment projects", Journal of Building Engineering, 24, 100697.

51. Egan, J., 1998. Rethinking construction. HMSO London Dep. Environ. 129.

52. Elmualim, A., Gilder, J., 2014. BIM: Innovation in design management, influence and challenges of implementation. Archit. Eng. Des. Manag. 10, pp. 183-199.

53. Erol, H., Dikmen, I., Birgonul, M.T., 2017. Measuring the impact of lean construction practices on project duration and variability: A simulation-based study on residential buildings. J. Civ. Eng. Manag. 23, pp. 241-251.

54. Fazli, A., Fathi, S., Enferadi, M.H., Fazli, M., Fathi, B., 2014. Appraising Effectiveness of Building Information Management (BIM) in Project Management. Procedia Technol. 16, pp. $1116-1125$.

55. Fond, P., 2009. Lean and Low Environmental Impact Manufacturing, in: POMS 20th Annual Conference Orlando, FL, U.S.A. 1-4 May 2009.

56. Gan, V.J.L., Deng, M., Tse, K.T., Chan, C.M., Lo, I.M.C., Cheng, J.C.P., 2018. Holistic BIM framework for sustainable low carbon design of high-rise buildings. J. Clean. Prod. 195, pp. 1091-1104. 
57. Gerber, D.J., Becerik-Gerber, B., Kunz, A., 2010. Building Information Modeling and Lean Construction: Technology, Methodology and Advances from Practice. 18th Annu. Conf. pp. 1-11.

58. Gibbs, D.-J., Emmitt, S., Lord, W., Ruikar, K., 2015. BIM and construction contracts CPC 2013's approach. Manag. Procure. Law 168, pp. 285-293.

59. Giel, B., Issa, R.R.A. (2013). Return on investment analysis of using building information modeling in construction. J Comput in Civ Eng 27(5):511-521

60. Hammond, R., Nawari, N., Walters, B. (2014). BIM in sustainable design: strategies for retrofitting/renovation. Computing in Civil and Building Engineering, ASCE (2014), pp. 1969-1977.

61. Hamzeh, F. (2009). Improving Construction Workflow- The Role of Production Planning and Control. UC Berkeley.

62. Heffernan, E., Pan, W., Liang, X., De Wilde, P., 2015. Zero carbon homes: Perceptions from the housebuilding industry. Energy Policy 79, pp. 23-36.

63. Hongling, G., Yantao, Y., Weisheng, Z., Yan, L., 2016. BIM and Safety Rules Based Automated Identification of Unsafe Design Factors in Construction. Procedia Eng. 164, pp. 467-472.

64. Horta, I.M., Camanho, A.S., Da Costa, J.M., 2010. Performance Assessment of Construction Companies Integrating Key Performance Indicators and Data Envelopment Analysis. J. Constr. Eng. Manag. 136, pp. 581-594.

65. Howell, G.A. (1999). What Is Lean Construction? Proceeding Seventh Annual Conference of International Group of Lean Construction, IGLC-7, University Of California, Berkeley, CA, USA (1999). 
66. Ilhan, B., Yaman, H., 2016. Green building assessment tool (GBAT) for integrated BIMbased design decisions. Autom. Constr. 70, pp. 26-37.

67. Inyim, P., Rivera, J., Zhu, Y., 2014. Integration of Building Information Modeling and Economic and Environmental Impact Analysis to Support Sustainable Building Design. J. Manag. Eng. 31, pp. 1-10.

68. Issa, U.H., 2013. Implementation of lean construction techniques for minimizing the risks effect on project construction time. Alexandria Eng. J. 52 (4), pp. 697-704.

69. Jalaei, F., Jrade, A., 2015. Integrating building information modeling (BIM) and LEED system at the conceptual design stage of sustainable buildings. Sustain. Cities Soc. 18, pp. 95-107.

70. Kadry, S., 2013. Six Sigma Methodology for the Environment Sustainable Development. Luo Z. Mech. Des. Sustain. Springer, Dordr. pp. 61-76.

71. Kagioglou, M., Cooper, R., Aouad, G. (2001). Performance management in construction: a conceptual framework. Construction Management and Economics (2001) 19, 85-95

72. Kent, D.C., Becerik-Gerber, B., 2010. Understanding construction industry experience and attitudes toward Integrated Project Delivery. J. Constr. Eng. Manag. 136, pp. 815825.

73. Khanzode, A., Fischer, M.A., Reed, D., Ballard, G., 2006. A Guide to Applying the Principles of Virtual Design \& Construction (VDC) to the Lean Project Delivery Process. CIFE, Stanford Univ. Palo Alto, Calif.

74. Khatatbeh, A.A.., 2015. The Effects of Building Information Modeling on Construction (Productivity and Cost). J. Inf. Eng. Appl. 5, (7). pp. 13-21. 
75. Kiani Mavi, R., Standing, C., 2018. Critical success factors of sustainable project management in construction: A fuzzy DEMATEL-ANP approach. J. Clean. Prod. 194, pp. 751-765.

76. King, A., Lenox, M., 2001. Lean and green? An empirical examination of the relationship between lean production and environmental performance. Prod. Oper. Manag. 10, pp. 244-256.

77. Kleindorfer, P.R., Singhal, K., Wassenhove, L.N., 2009. Sustainable Operations Management. Prod. Oper. Manag. 14, pp. 482-492.

78. Koranda, C., Chong, W.K., Kim, C., Chou, J.S., Kim, C., 2012. An investigation of the applicability of sustainability and lean concepts to small construction projects. KSCE J. Civ. Eng. 16, pp. 699-707.

79. Koskela, L., 1992. Application of the new production philosophy to construction Tech. Report No. 72, CIFE, Stanford University, CA.

80. Koskela, L., 2000. An exploration towards a production theory and its application to construction. Espoo 2000. Technical Research Centre of Finland, VTT Publications 408. 296 p.

81. Koskela, L., G. Howell, G. Ballard, and I. Tommelein (2002). "Foundations of Lean Construction." Chapter 14 in Best \& de Valence (editors), Design and Construction: Building in Value. Butterworth-Heineman.

82. Kurdve, M., Shahbazi, S., Wendin, M., Bengtsson, C., 2015. Waste flow mapping to improve sustainability of waste management: a case study approach. J. Clean. Prod. 98, pp. 304-315. 
83. Laureani, A., Antony, J., 2012. Critical success factors for the effective implementation of Lean Sigma: Results from an empirical study and agenda for future research. Int. J. Lean Six Sigma 3, pp. 274-283.

84. Lee, S., Yu, J., Jeong, D., 2015. BIM Acceptance Model in Construction Organizations. J. Manag. Eng. 31 (3), 04014048.

85. Liao, L., Teo, E.A.L., 2017. Critical Success Factors for enhancing the Building Information Modelling implementation in building projects in Singapore. J. Civ. Eng. Manag. 23, pp. 1029-1044.

86. Liu, J., Low, S.P., Wang, L.F., 2017. Critical success factors for eco-city development in China. Int. J. Constr. Manag. pp 1-10.

87. Liu, R., Issa, R., Olbina, S. (2010). Factors influencing the adoption of building information modeling in the AEC Industry. Paper presented at the Proceedings of the International Conference on Computing in Civil and Building Engineering (2010).

88. Liu, Z., Osmani, M., Demian, P., Baldwin, A.N., 2011. The potential use of BIM to aid construction waste minimisation. CSTB -International Conf. 53.

89. Lou, E.C.W. and Alshawi, M. (2009), Critical Success Factors for E-Tendering Implementation in Construction: People and Process Issues, Journal of Information Technology in Construction (ITCon), 14, 98-109

90. Love, P.E.D., Edwards, D.J., Han, S., Goh, Y.M., 2011. Design error reduction: toward the effective utilization of building information modeling. Res. Eng. Des. 22, pp. 173187.

91. Lu, Y., Wu, Z., Chang, R., Li, Y., 2017. Building Information Modeling (BIM) for green buildings: A critical review and future directions. Autom. Constr. 83, pp. 134-148. Ma, 
Z., Zhang, D., Li, J., 2018. A dedicated collaboration platform for Integrated Project Delivery. Autom. Constr. 86, pp. 199-209.

92. Mahalingam, A., Yadav, A.K., Varaprasad, J., 2015. Investigating the Role of Lean Practices in Enabling BIM Adoption: Evidence from Two Indian Cases. J. Constr. Eng. Manag. 141 (7): 05015006.

93. Malekitabar, H., Ardeshir, A., Sebt, M.H., Stouffs, R., 2016. Construction safety risk drivers: A BIM approach. Saf. Sci. 82, pp. 445-455.

94. Mao, X., Zhang, X., 2008. Construction Process Reengineering by Integrating Lean Principles and Computer Simulation Techniques. J. Constr. Eng. Manag. 134, pp. 371381.

95. Marhani, M.A., Jaapar, A., Bari, N.A.A., Zawawi, M., 2013. Sustainability Through Lean Construction Approach: A Literature Review. Procedia - Soc. Behav. Sci. 101, pp. 9099.

96. Marodin, G.A., Saurin, T.A., 2013. Implementing lean production systems: Research areas and opportunities for future studies. Int. J. Prod. Res. 51, pp. 6663-6680.

97. Mellado, F., Lou, E. and Becerra, C. 2019. Synthesising performance in the construction industry, Engineering, Construction and Architectural Management, 27(2), 579-608

98. Mellado, F., Wong, P.F., Amano, K., Johnson, C. and Lou, E.C.W. 2020. Digitisation of existing buildings to support building assessment schemes: viability of automated sustainability-led design scan-to- BIM process. Architectural Engineering and Design Management, 16(2), 84-99.

99. Mollasalehi, S., Aboumoemen, A.A., Rathnayake, A., Underwood, J., 2018. Development of an Integrated BIM and Lean Maturity Model, in: 26th Annual 
Conference of the International Group for Lean Construction (IGLC), Chennai, India. pp. 1217-1228.

100. Mollenkopf, D., Stolze, H., Tate, W., Ueltschy, M., 2010. Green, lean, and global supply chains. Int. J. Phys. Distrib. Logist. Manag. 40, pp. 14-41.

101. Moreno, C., Olbina, S., Issa. R. R. 2019. BIM use by architecture, engineering, and construction (AEC) industry in educational facility projects. Advances in Civil Engineering. 2019, 1392684.

102. Nascimento, D.L. de M., Sotelino, E.D., Lara, T.P.S., Caiado, R.G.G., Ivson, P. 2017. Constructability in industrial plants construction: a BIM-Lean approach using the Digital Obeya Room framework. J. Civ. Eng. Manag. 23, 1100-1108.

103. Navendren, D., Manu, P., Shelbourn, M., Mahamadu, A., 2014. Challenges to building information modelling implementation in UK: Designers' perspectives. Proc. 30th Annu. ARCOM Conf. Portsmouth, 1-3 Sept. 2014. UK Assoc. Res. Constr. Manag. 733742.

104. Ng, R., Low, J.S.C., Song, B., 2015. Integrating and implementing Lean and Green practices based on proposition of Carbon-Value Efficiency metric. J. Clean. Prod. 95, 242-255.

105. Nguyen, P., Akhavian, R. 2019. Synergistic effect of integrated project delivery, lean construction, and Building Information Modeling on project performance measures: A quantitative and qualitative analysis. Adv. Civ. Eng. 2019, 1267048.

106. Nikakhtar, A., Hosseini, A.A., Wong, K.Y., Zavichi, A., 2015. Application of lean construction principles to reduce construction process waste using computer simulation: a case study. Int. J. Serv. Oper. Manag. 20, 461-480. 
107. Nitin, S., Dinesh, K., Paul, S.T., 2011. TQM for manufacturing excellence: Factors critical to success. Int. J. Appl. Eng. Res. 2, pp. 219-233.

108. Nowotarski, P., Pasawski, J., Matyja, J., 2016. Improving Construction Processes Using Lean Management Methodologies - Cost Case Study. Procedia Eng. 161, pp. 10371042.

109. Ochoa, J.J., 2014. Reducing plan variations in delivering sustainable building projects. J. Clean. Prod. 85, 276-288.

110. Ogunbiyi, O., Goulding, J.S., Oladapo, A., 2014. An empirical study of the impact of lean construction techniques on sustainable construction in the UK. Constr. Innov. 14, 88-107.

111. Olawumi, T.O., Chan, D.W.M., 2018. Critical Success Factors (CSFs) for amplifying the integration of BIM and sustainability principles in construction projects: A Delphi study, in: The Construction, Building and Real Estate Research Conference of the Royal Institution of Chartered Surveyors.

112. Ozorhon, B., Karahan, U., 2016. Critical Success Factors of Building Information Modeling Implementation. J. Manag. Eng. 33, 1-10.

113. Pagell, M., Wu, Z.H., 2009. Building a more complete theory of sustainable supply chain management using case studies of 10 exemplars. J. Supply Chain Manag. 45, 3756.

114. Pan, S.Y., Du, M.A., Huang, I.T., Liu, I.H., Chang, E.E., Chiang, P.C. 2015. Strategies on implementation of waste-to-energy (WTE) supply chain for circular economy system: a review J. Clean. Prod., 108, 409-421.

115. Peng, W., Pheng, L., 2010. Lean production, value chain and sustainability in precast concrete factory-a case study in Singapore. Lean Constr. 92-109. 
116. Prins, M., Owen, R., 2010. Integrated design and delivery solutions. Archit. Eng. Des. Manag. 6, 227-231.

117. Rischmoller, L., Alarcón, L.F., Koskela, L., 2006. Improving Value Generation in the Design Process of Industrial Projects Using CAVT. J. Manag. Eng. 22, 52-60.

118. Rosenbaum, S., Toledo, M., González, V., 2014. Improving Environmental and Production Performance in Construction Projects Using Value-Stream Mapping: Case Study. J. Constr. Eng. Manag. 140, 1-11.

119. Sacks, R., Koskela, L., Dave, B.A., Owen, R., 2010. Interaction of Lean and Building Information Modeling in Construction. ASCE J. Comput. Civ. Eng. 136, 968-980.

120. Sacks, R., Treckmann, M., Rozenfeld, O., 2009. Visualization of Work Flow to Support Lean Construction. J. Constr. Eng. Manag. 135, 1307-1315.

121. Saieg, P., Sotelino, E.D., Nascimento, D., Gusmao Caiado, R.G., 2018. Interactions of Building Information Modeling, Lean and Sustainabilityon the Architectural, Engineering and Construction industry: Asystematic review. J. Clean. Prod. 174, 788806.

122. Salem, O., Solomon, J., Genaidy, A., Luegring, M., 2005. Site Implementation and Assessment of Lean Construction Techniques. Lean Constr. J. 2, 1-21.

123. Salem, O., Solomon, J., Genaidy, A., Minkarah, I., 2006. Lean construction: from theory to implementation. J. Manag. Eng. 4, 10-19.

124. Sarhan, J.G., Olanipekun, A.O., Xia, B., 2016. Critical Sucess Factors for Implementation of Lean Construction in Saudi Arabian Construction Industry, in: Proceeding of the International Conference on Sustainable Built Environment. 338-341.

125. Sarhan, S., Fox, A., 2013. Barriers to Implementing Lean Construction in the UK Construction Industry. Built Hum. Environ. Rev. 6, 1-17. 
126. Saunders, M., Lewis, P., Thornhill, A., 2008. Research Methods for Business Students, Research methods for business students. Pearson Education.

127. Seppänen, O., Ballard, G., Pesonen, S., 2010. The combination of last planner system and location-based management system. Lean Constr. J., 43-54.

128. Sfakianaki, E., 2018. Critical success factors for sustainable construction: a literature review. Manag. Environ. Qual. An Int. J. 30(1), 176-196.

129. Shang, Z., Shen, Z., 2014. Critical Success Factors (CSFs) of BIM Implementation for Collaboration based on System Analysis, in: International Conference on Computing in Civil and Building Engineering. p. June 23-25, Orlando, Florida.

130. Shou, W., Wang, X., Wang, J., Hou, L., Truijens, M., 2014. Integration of BIM and Lean Concepts to Improve Maintenance Efficiency: A Case Study. Int. Conf. Comput. Civ. Build. Eng. June 23-25, 373-380.

131. Shub, A.N., Stonebraker, P.W., 2009. The human impact on supply chains: Evaluating the importance of "soft" areas on integration and performance. Supply Chain Manag. $14,31-40$.

132. Sila, I., Ebrahimpour, M., 2003. Examination and comparison of the critical factors of total quality management (TQM) across countries. Int. J. Prod. Res. 41, 235-268.

133. Simboli, A., Taddeo, R., Morgante, A., 2014. Value and Wastes in Manufacturing. An Overview and a New Perspective Based on Eco-Efficiency. Adm. Sci. 4, 173-191.

134. Singh, V., Gu, N., Wang, X., 2011. A theoretical framework of a BIM-based multidisciplinary collaboration platform. Autom. Constr. 20, 134-144.

135. Small, H. M., \& Yasin, M. M., 2011. Assessing the implementation and effectiveness of process management initiatives at technologically consistent firms Business Process Management, 6-20. 
136. Smith, P., 2014. BIM implementation - Global strategies. Procedia Eng. 85, 482-492.

137. Succar, B., 2009. Building information modelling framework: A research and delivery foundation for industry stakeholders. Autom. Constr. 18, 357-375.

138. Suermann, P.C., Issa, R.R.A., 2009. Evaluating industry perceptions of building information modeling (BIM) impact on construction. Electron. J. Inf. Technol. Constr. $14,574-594$.

139. Tauriainen, M., Marttinen, P., Dave, B., Koskela, L., 2016. The effects of BIM and lean construction on design management practices. Procedia Eng. 164, 567-574.

140. Teo, E.A.L., Ofori, G., Tjandra, I.K., Kim, H., 2015. The Potential of Building Information Modelling (BIM) for Improving Productivity in Singapore Construction. Procs 31st Annu. ARCOM Conf. 661-670.

141. Thomas, H.R., Horman, M.J., Minchin, R.E., Chen, D., 2003. Improving Labor Flow Reliability for Better Productivity as Lean Construction Principle. J. Constr. Eng. Manag. 129, 251-261.

142. Toledo, M., Olivares, K., González, V., 2016. Exploration of a Lean-BIM Planning Framework: A Last Planner System and BIM-Based Case Study. Proc. 24th Ann. Conf. Int. Gr. Lean Constr. Boston, MA, USA, 3-12.

143. Toor, S. u R., Ogunlana, S.O., 2010. Beyond the "iron triangle": Stakeholder perception of key performance indicators (KPIs) for large-scale public sector development projects. Int. J. Proj. Manag. 28, 228-236.

144. UKGBC. 2017. Delivering Low Carbon Infrastructure, UK Green Building Council, London. 
145. Vukomanovic, M., Radujkovic, M., Nahod, M., 2014. EFQM excellence model as the TQM model of the construction industry of south-eastern Europe. J.Civ.Eng.Manag. $20,70-81$

146. Wadhwa, R.S., 2014. Synergizing Lean and Green for Continuous Improvement. IFIP Adv. Inf. Commun. Technol. 439, 154-161.

147. Walasek, D., Barszcz, A., 2017. Analysis of the Adoption Rate of Building Information Modeling [BIM] and its Return on Investment [ROI]. Procedia Eng. 172, 1227-1234.

148. Wang, W., Weng, S., Wang, S., Chen, C., 2014. Integrating building information models with construction process simulations for project scheduling support. Autom. Constr. $37,68-80$.

149. Wang, X., Chong, H.Y., 2015. Setting new trends of integrated Building Information Modelling (BIM) for construction industry. Constr. Innov. 15, 2-6.

150. Webster, J., Watson, R.T., 2002. Analyzing the Past to Prepare for the Future: Writing a Literature Review. Manag. Inf. Syst. Res. Cent. 26, 13-23.

151. Whelton, M., Ballard, G., Tommelein, I. D. (2002). A knowledge management framework for project definition. Electron J. Inf. Technol. Constr., 7, 197-212.

152. Won, J., Lee, G., Dossick, C., Messner, J., 2013. Where to Focus for Successful Adoption of Building Information Modeling within Organization. J. Constr. Eng. Manag. 139, 112.

153. Wong, J.K.W., Kuan, K.L., 2014. Implementing "BEAM Plus" for BIM-based sustainability analysis. Autom. Constr. 44, 163-175.

154. Wong, J.K.W., Zhou, J., 2015. Enhancing environmental sustainability over building life cycles through green BIM: A review. Autom. Constr. 57, 156-165. 
155. Wong, K., Fan, Q., 2013. Building information modelling (BIM) for sustainable building design. Facilities 31, 138-157.

156. Wong, W.P., Wong, K.Y., 2014. Synergizing an ecosphere of lean for sustainable operations. J. Clean. Prod. 85, 51-66.

157. Wu, W., Issa, R.R.A., 2015. BIM Execution Planning in Green Building Projects: LEED as a Use Case. J. Manag. Eng. 31, A4014007.

158. Xie, X., Lu, Y., Gou, Z., 2017. Green building pro-environment behaviors: Are green users also green buyers? Sustain. 9, 1-13.

159. Xiong, X., Adan, A., Akinci, B., Huber, D. 2013. Automatic creation of semantically rich 3D building models from laser scanner data Autom. Constr. 31, 325-337.

160. Xu, P.P., Chan, E.H.W., Qian, Q.K., 2012. Key performance indicators (KPI) for the sustainability of building energy efficiency retrofit (BEER) in hotel buildings in China. Facilities 30, 432-448.

161. Yaakob, M., Ali, W.N.A.W., Radzuan, K., 2016. Identifying critical success factors (CSFs) of implementing building information modeling (BIM) in Malaysian construction industry. AIP Conf. Proc. 1761.

162. Yun, S. Heon, Jun, K. Hyun, Son, C. Baek, Kim, S. Chul., 2014. Preliminary study for performance analysis of BIM-based building construction simulation system. KSCE J. Civ. Eng. 18, 531-540.

163. Zhang, S., Sulankivi, K., Kiviniemi, M., Romo, I., Eastman, C.M., Teizer, J., 2015. BIMbased fall hazard identification and prevention in construction safety planning. Saf. Sci. 72, 31-45. 
164. Zhang, S., Teizer, J., Lee, J.K., Eastman, C.M., Venugopal, M., 2013. Building Information Modeling (BIM) and Safety: Automatic Safety Checking of Construction Models and Schedules. Autom. Constr. 29, 183-195.

165. Zhou, P., El-Gohary, N. (2018). Automated matching of design information in BIM to regulatory information in energy codes. In: Construction Research Congress 2018, April 2-4, New Orleans, Louisiana, USA.

166. Zimina, D., Ballard, G., Pasquire, C. (2012). Target value design: using collaboration and a lean approach to reduce construction cost, Construction Management and Economics, 30(5), 383-398. 